\title{
LIQUIDITY AS AN ASSET PRICING FACTOR IN THE UK
}

\author{
PANAYIOTIS G. ARTIKIS \\ Department of Business Administration \\ University of Piraeus \\ 80 Karaoli and Dimitriou Street \\ 18532 Piraeus, Greece \\ partikis@unipi.gr
}

Received 12 March 2018

Accepted 4 October 2018

Published 13 December 2018

\begin{abstract}
This study examines whether there is a strong relationship between stock liquidity, which proxies for the implicit cost of trading shares, and future stock returns in an asset-pricing context in the UK stock market. The time period, 1994-2016, includes the most recent global financial crisis that drained liquidity from financial markets worldwide. Four different measures of stock liquidity are employed; the empirical findings indicate that liquidity is a systematic pricing factor and explains a significant portion of the variation in stock returns, even after the inclusion of the other traditional risk factors. The results are robust to both forms of liquidity, either as a residual effect or in its original form as a separate risk factor. Finally, for the first time quantile regression is applied, showing that the liquidity risk factor (LIQ) absorbs a significant portion of the information content of the size and value factors, while remaining independent of the momentum factor.
\end{abstract}

Keywords: Liquidity measures; liquidity risk; UK stock exchange; asset pricing; factor model; quantile regression.

JEL Classification: G11, G12, G15

\section{Introduction}

The main assumption of the classical asset pricing models is that investors do not face any frictions in financial markets especially in terms of trading costs. However, in real life situations, investors face liquidity risk which actually captures the implicit cost for trading securities. Liquidity plays a very important role in asset management, portfolio performance and portfolio diversification strategies, either from retail or institutional investors, since they both face liquidity risk when they transfer the ownership of their securities. There are a number of occasions through the recent

This is an Open Access article published by World Scientific Publishing Company. It is distributed under the terms of the Creative Commons Attribution 4.0 (CC-BY) License. Further distribution of this work is permitted, provided the original work is properly cited. 
history of financial markets, such as the US market crash in 1987, the bankruptcy of the LTCM fund in 1998 and the recent global financial crisis, that pinpoint that the lack of liquidity is one of the most important market frictions that influence asset prices.

The aim of the present paper is to examine in depth the relationship between asset liquidity, based on firm-level data and expected stock returns. In doing so, liquidity is treated as an independent factor and we examine if liquidity is an assetpricing factor that can better explain stock return variability, after controlling for the well-known risk factors. Besides the traditional approach of OLS time-series regressions, we apply for the first time in the area of liquidity risk the methodology of quantile regression for four alternative liquidity proxies to all listed firms in the London Stock Exchange (LSE) from 1994 to 2016.

One of the earliest studies examining the impact of liquidity on stock returns is the one by Amihud \& Mendelson (1986), who document a positive relationship between excess returns and illiquidity with the use of the relative bid-ask spread. Since then, many scholars have examined the liquidity effect, using mainly data from the US and treating liquidity either as a stock characteristic (Amihud \& Mendelson, 1986, Eleswarapu \& Reinganum, 1993, Brennan \& Subrahmanyam, 1996, Datar et al. 1998, Chordia et al. 2000, 2001, Amihud, 2002, Cao \& Petrasek, 2014) or as separate risk factor (Chordia et al. 2000, Jacoby et al. 2000, Jones, 2002, Pastor \& Stambaugh, 2003, Acharya \& Pedersen, 2005, Liu, 2006, Sadka, 2006, Keene \& Peterson, 2007, Nguyen et al. 2007, Watanabe \& Watanabe, 2008, Chordia et al. 2009, Wang \& Chen, 2012, Brennan et al. 2012, 2013, Acharya et al. 2013).

Studies examining the effect of liquidity risk in the UK stock market are scarce. Galariotis \& Giouvris (2007) focus on the commonality of liquidity for the FTSE 100 and find that liquidity is dependent on the trading regimes. Lu \& Hwang (2007) examine the link between liquidity and the value premium in the UK and document that the value premium can be explained by a liquidity augmented CAPM. Foran et al. (2014), with the use of asymptotic principal component analysis, exhibit the existence of strong commonality across liquidity measures for the FTSE All Share constituent stocks. Thus, further evidence is needed in terms of market, methodological approaches and sample period, in order to fully understand the phenomenon.

The present study contributes to the literature towards this end in a number of ways. First, with the use of data from a European country (UK), that has a capital market oriented economy, an important contribution is made to the necessary accumulation of nonUS research. As pointed out by Lo \& MacKinlay (1990) asset pricing tests need to be examined with alternative datasets in order to avoid the data-snooping problem. The LSE is a major market of great international importance and interest, ranking among the world's largest in terms of number of firms listed and total market capitalization, hence, the results will be free as possible from infrequent trading and other biases. However, the UK market although its characteristics has a larger liquidity effect in comparison to the US market, making it a suitable ground for testing the liquidity effect in asset pricing outside the US. 
Furthermore, it should be taken into account that the different structure of the UK and the US stock exchanges leads to differences in liquidity characteristics (Huang \& Stoll, 2001). Specifically, in the UK, stocks are traded only in the LSE, whereas, in the US, trading takes place in two main exchanges, the NASDAQ and the NYSE. In UK, trading goes through a mix of order book and a hybrid quote/order book system, whereas, in the US, trading on the NYSE is based on a hybrid system and on the NASDAQ on an order book system. Thus, by investigating the pricing of liquidity risk in the UK market, we can make inferences of whether the different stock exchange structures will lead to different conclusions on the relationship between liquidity and stock returns already found in the pertinent US literature.

In terms of methodological approaches, the present study constructs liquidity risk factors in the context of the Fama-French framework, as opposed to the work of Foran et al. (2014) who use asymptotic principal component analysis for the construction of market liquidity factors. Our asset pricing models examine the effect of liquidity not only in its original form, as in the work of Foran et al. (2014) and Lu \& Hwang (2007), but also as a residual effect after controlling for the common risk factors (market risk premium, size, value and momentum). Most importantly however, it differentiates from previous work in the area by examining the relationship between liquidity and expected stock returns with the use for the first time of quantile regressions. Empirical studies in the area focus only on the traditional approach using the ordinary least squares in order to estimate a linear regression model. However, the traditional approach provides information only for the central tendency in a dataset. The advantage of the quantile regression approach is the estimation of various quantile functions in a conditional distribution, thus, describing in more detail the relationship between the dependent and independent variables. The rationale for using quantile regressions is to examine whether the relationship between liquidity risk and stock returns is stable across different points of the distribution.

Liquidity is an "elusive and slippery concept" (Kyle, 1985, p. 1316) and no liquidity proxy alone can capture all of its dimensions (Chai et al. 2013). Thus, the present study adopts four different liquidity proxies (Amihud's illiquidity ratio, relative spread (RS), turnover (TVR) and volume traded) that are constructed from low frequency data, as opposed to the work of Lu \& Hwang (2007) and Foran et al. (2014) who use the modified relative Amihud's illiquidity ratio (ILR) and proxies based on high-frequency tick data, respectively. All proxies applied in the present study can be easily calculated, do not require the restrictive assumptions of the more sophisticated ones, such as the Lesmond et al. (1999) and Roll (1984) measures, are valid for use in asset pricing tests (Goyenko et al. 2009) and are able to capture the tightness, depth and resiliency transactional properties of the markets (Chai et al. 2013).

Finally, as far as the sample period is concerned, the present study is performed in a unique and interesting time frame, i.e. 1994-2016, since it covers both periods of 
"bull" and "bear" equity markets and periods of economic expansion and economic downturn. In particular, the second period of recession was quite severe, following the burst of the real estate bubble in the US, which triggered the global financial crisis that drained liquidity from financial markets worldwide, highlighting awareness among investors of the importance of taking liquidity into account when making their investment decisions (Brunnermeier, 2008, Longstaff, 2010). Thus, our empirical models are tested across a number of different economic and stock markets backgrounds. Additionally, the LSE is a very attractive market on an international level (Galariotis \& Giouvris, 2007), thus, the implications of our results may be of particular interest not only for academics, but also for investors (retail and institutional) and/or policy makers-regulators.

The results indicate that liquidity in both forms, residual and original, proves to be an important factor for pricing the cross section of stock returns in the UK stock exchange. The importance of the liquidity risk factor (LIQ) remains even after we have controlled for the traditional risk factors (market risk premium, size, value and momentum). Furthermore, the LIQ absorbs the information content from the size and value factors, while it is independent of the information content of the momentum factor.

\section{Literature Review}

Liquidity, despite the attention it has received in the literature, still remains an elusive concept and is very difficult to be defined accurately. One way that asset liquidity can be thought of is the ability to buy or sell an investment instantly and at a price close to its current market price (Chai et al. 2010, Brennan et al. 2012, Papavassiliou, 2013).

Scholars have treated liquidity initially as a stock characteristic. Specifically, Eleswarapu \& Reinganum (1993) show that liquidity, proxied by spread premium, is reliably positive only during January. Brennan \& Subrahmanyam (1996) find that there is a significant return premium associated with both fixed and variable elements of the cost of transacting. Datar et al. (1998) and Chordia et al. (2000) find that there is a strong negative relation between average returns and trading volume, which is consistent with a liquidity premium in asset prices. Chordia et al. (2001) conclude that liquidity, proxied by volatility of trading activity has a negative and strong cross sectional relationship with the stock returns. Amihud (2002) finds that expected market illiquidity positively affects ex ante stock excess returns, suggesting that expected stock return partly represents an illiquidity premium. Cao \& Petrasek (2014) find that during liquidity crises stock returns are strongly related to the liquidity beta.

Other studies in the area focus on liquidity as a separate risk factor. Specifically, Chordia et al. (2000) indicate that a significant proportion in the effect of liquidity on stocks can be attributed to the common influences between stock liquidity and market-wide liquidity. Jacoby et al. (2000) develop a CAPM-based model to 
examine the relationship between expected returns and spread cost. They find that the relationship is positive and convex, supporting the evidence brought forward by Brennan \& Subrahmanyam (1996). Jones (2002) presents evidence that the transaction cost measures, that also acts as proxy for liquidity-spreads and TUR, predict returns for one year or more ahead. High spreads predict high stock returns, while high TUR predicts low stock returns. Pastor \& Stambaugh (2003) find that market wide liquidity appears to be a state variable that is important for pricing common stocks.

Acharya \& Pedersen (2005) by decomposing the Jacoby et al. (2000) liquidity adjusted beta develop a liquidity-adjusted capital asset pricing model (LCAPM). Their model incorporates three different types of liquidity risk, i.e. the covariance of liquidity with market liquidity, the covariance of liquidity with market return and the covariance of return with market liquidity, which are all independent of traditional market risk. Liu (2006) develops a new measure of liquidity and documents a significant liquidity premium that is robust even in the presence of the CAPM and Fama-French model factors. He proposes a two-factor pricing model, including the market risk premium and the liquidity factor that explains the cross section of stock returns. Sadka (2006) shows that systematic liquidity risk is a priced risk factor. Keene \& Peterson (2007) and Nguyen et al. (2007) find evidence in support of Amihud \& Mendelson (1986). They show that liquidity is an important factor in pricing returns even in the presence of the factors from the three-moment CAPM, the Fama-French model and the Pastor \& Stambaugh (2003) model. Watanabe \& Watanabe (2008) find that liquidity betas vary across a two distinct states of high liquidity beta and low betas.

In more recent studies, Chordia et al. (2009) consider theory-based illiquidity estimates that can be estimated by way of closed-form expressions and show that they are priced in the cross section of stock returns. Wang \& Chen (2012), by utilizing a general stochastic discount factor pricing framework, derive a liquidityadjusted conditional two and three-moment CAPM and show that the risk premium for a risky asset depends on four liquidity related factors. Acharya et al. (2013) document that the effect of adverse liquidity shocks is positive for low book-tomarket ratio stocks in times of economic distress. Brennan et al. (2012) provide evidence that support the notion that the pricing of liquidity emanates almost entirely from sell-orders. Brennan et al. (2013), by decomposing the Amihud liquidity measure into up and down return days, show that only the down day element contains a return premium. Finally, Hur et al. (2018) results imply that a risk factor based on the liquidity premium measure not only explains cross-sectional stock returns, but also time-series excess returns on portfolios sorted on the commonly used liquidity measure. Their findings suggest that better understanding the liquidity risk leads to sustainable trading for investors.

On the other hand, there are a number of recent studies that doubt the liquidity premium. Drienko et al. (2018) take a comprehensive look at the results of 
Amihud (2002) who finds a strong relationship between liquidity and stocks returns. They conclude that the results found in Amihud's paper only hold in-sample. Using data from the last two decades, the authors find that the liquidity risk is not rewarded, possibly due to the technological innovations that have increased average stock-level liquidity. Hou et al. (2017) find that the vast majority of the documented liquidity measures are completely insignificant if one gives less weight to microcaps in portfolio construction. Finally, Li et al. (2017) find that the performance of the Pastor \& Stambaugh (2003) liquidity factor is very sensitive to how it is constructed, and that if the standard Fama \& French (1993) methodology is used then it generates a statistically insignificant return.

All the above-mentioned studies refer solely to the US market. However, there are a number of studies that examine the pricing of liquidity risk outside the US utilizing global datasets. Lee (2011) tests the LCAPM of Acharya \& Pedersen (2005) on an aggregate level for 22 developed and 28 emerging markets and finds that liquidity risk appears to be stronger in developing countries. In the same context, Donadelli \& Prosperi (2012) document that the global liquidity factors predict excess returns in emerging markets. Also, Bekaert et al. (2007) using data from 18 emerging stock markets find that liquidity is a priced factor and predicts future returns. Liang \& Wei (2012) focus on 21 developed markets show that global liquidity risk is priced in developed country market portfolios. However, they do not find significant results on the pricing premium for the local liquidity risk measure for UK. Finally, Amihud et al. (2013) examine the illiquidity premium in 45 countries and find that the premium is higher for emerging markets than developed.

Studies for individual countries outside the US, among others, include Chang et al. (2010) for Japan, Lam \& Tam (2011) for Hong Kong, Narayan \& Zheng (2010) for China, Martinez et al. (2005) for Spain, Papavassiliou (2013) for Greece and Hur \& Chung (2018) for Korea. All these studies provide evidence on the pricing effect of liquidity. Chan \& Faff (2005) and Limkriangkrai et al. (2008) examine the Australian market and conclude that liquidity, proxied by the TUR, plays an important role in asset pricing. In contrast, Anderson et al. (1997), Marshall \& Young (2003), Gharghori et al. (2007), Chai et al. (2013) and Nguyen \& Lo (2013) do not find strong evidence that liquidity risk is priced in asset returns.

Compared to the U.S. literature, there is little research, to our knowledge, on the pricing of liquidity risk in the UK stock market. Galariotis \& Giouvris (2007) expand the work of Huberman \& Halka (2001) and show strong commonality among FTSE 100 stocks. Additionally, they document that systematic liquidity is sensitive to the nature of trading regimes. Lu \& Hwang (2007) examine the pricing of illiquidity and find that liquidity along with book-to-market equity (BE/ME) ratio explains the cross section of stock returns in UK. Foran et al. (2014) employ asymptotic principal component analysis and use high-frequency tick data to construct microstructure liquidity proxies in order to capture commonality in liquidity across UK stocks. They find that liquidity risk confers a significant risk premium in normal market conditions and strong commonality across liquidity measures. 


\section{Data and Methodology}

\subsection{Sample stocks}

The sample consists of all stocks listed on the LSE from 31/12/1994 to 31/12/2016. Closing stock prices, bid/ask prices, trading volume, total number of shares listed, market capitalization, index market prices, accounting data and risk-free rates of return are sourced from Bloomberg.

\subsection{Liquidity proxies}

The main objective of the present study is to examine if liquidity risk is priced in the cross section of sock returns. In order to achieve the main objective, the first step of the methodology involves the calculation of different liquidity measures for the stocks of the sample. In the literature there are numerous liquidity indicators that try to capture stock market liquidity, since no liquidity proxy alone can fully capture all of its dimensions (Chai et al. 2010).

The high-frequency liquidity measures are more precise than low-frequency measures (Hasbrouck, 2009), however, they require intraday data on bid/ask quotes, order flow, volume of trades etc. which are not available for a long period of time. Thus, we adopt low-frequency liquidity measures, which can be estimated with intraday data that are available for longer periods of time. Furthermore, Goyenko et al. (2009) and Fong et al. (2014) show that low-frequency liquidity measures capture high-frequency measures and can be used in asset pricing tests.

We use four liquidity measures: (a) the Amihud (2002) ILR, (b) the RS, (c) TUR and (d) Volume of trading (VTR). According to Goyenko \& Ukhov (2009) and Goyenko et al. (2009) the first two liquidity proxies are able to capture the spread cost and the price impact. The rationale for using TUR and VTR is that they are simple and straightforward to calculate and do not require a large amount of data or restrictive assumptions as the more sophisticated proxies, such as the Lesmond et al. (1999) and Roll (1984) liquidity measures.

Amihud's (2002) ILR is the ratio of absolute stock return to monetary volume on a daily basis, showing how much the price moves for each monetary unit of trades. The cost associated with larger trades is more accurately captured in the price impact of a trade. Hasbrouck (2009) shows that the ILR is the best available priceimpact proxy constructed from daily data and that it is strongly correlated with microstructure based data. Amihud (2002) shows that the ILR is positively and significantly related to both the price impact and the fixed cost component estimates of Brennan \& Subrahmanyam (1996). Fong et al. (2014) document that the ILR is the best daily cost-per-volume liquidity proxy. The ILR tries to capture the sensitivity of prices to trading volume, since it is a measure of the elasticity dimension of liquidity. The ILR is calculated as

$$
\mathrm{ILR}_{i, T}=1 / D_{T} \sum_{t=1}^{T} \frac{\left|R_{i, t}\right|}{\mathrm{VOL}_{i, t}},
$$


where $D_{T}$ is the number of observations within a time window $T,|R i, t|$ is the absolute return on day $t$ for stock $i$, and $\mathrm{VOL}_{i, t}$ is the trading volume in monetary values on day $t$ for stock $i$. The ILR is multiplied by $10^{6}$ for practical purposes and provides in essence an illiquidity measure since a high value indicates low liquidity (high price impact of trades). Moreover, a high price impact suggests that the market depth is low, and as such a smaller volume is needed to move the price.

A market participant who wishes to fill his order immediately must be willing to pay the ask price for a buy order and collect the bid price for a sell order. The difference between the two prices is the bid-ask spread, which reflects the cost of immediacy. Thus, the bid-ask is a spread cost that is observed in both dealer and limit order markets. In the present study, we estimate a market-wide proportional spread measure, the relative bid/ask spread (RS). It is estimated as the ratio of the quoted spread (defined as the difference between the best ask and bid quotes) over the midpoint price (defined as the average of the best ask and bid quotes) on a daily basis:

$$
\mathrm{RS}_{i, T}=1 / D_{T} \sum_{t=1}^{T} \frac{\left(P_{i, t}^{\mathrm{ASK}}-P_{i, t}^{\mathrm{BID}}\right)}{\left(P_{i, t}^{\mathrm{ASK}}+P_{i, t}^{\mathrm{BID}}\right) / 2},
$$

where $P_{i, t}^{\mathrm{ASK}}$ and $P_{i, t}^{\mathrm{BID}}$ is the ask and bid price respectively on day $t$ for stock $i$. The $\mathrm{RS}$ provides a relative measure of trading costs and proxies for a percentage two-way transaction cost, i.e. what fraction of the price needs to be paid to "cross" from the bid to the ask price, or vice versa. Like the ILR the RS is an illiquidity measure, since a high spread indicates an illiquid market where the implicit costs of trading is large.

TUR is a common measure of activity, and is calculated as the total number of shares traded during a time interval, relative to the number of outstanding shares in the security. We express TUR in percentage terms, thus, TUR measures the percentage of the issued shares that changes hands during a trading window (e.g. day, month, quarter). Finally, the VTR in monetary terms is calculated by multiplying the number of shares traded by the concurrent stock price. Both the TUR and VTR are liquidity measures as opposed to the ILR and RS, which are illiquidity measures. According to Kyle (1985), the concept of liquidity embraces the tightness, depth and resiliency properties of markets. The RS reflects trading costs and reveals the tightness of the market, the ILR is related to depth, since it measures price movement against trading volume and TUR and VTR capture the resiliency characteristic, since they measure trading frequency (Chai et al. 2010). All four liquidity proxies are estimated for each stock on a monthly basis.

\subsection{Regression factors}

The market risk premium is calculated as the monthly logarithmic return of a market portfolio in excess of the risk-free rate. The market return is approximated by the FTSE100 Index and as a risk-free asset the return of the 12-month government Treasury bill is used. 
The other independent factors are the Fama \& French (1993) size (SMB) and value factor (HML), the Carhart (1997) momentum factor (WML) and a liquidity factor. At the end of June of each year, all sample stocks are independently sorted: (a) by size (capitalization), measured at the end of June, and allocated into two size bisects, (b) on their BE/ME, measured at the end of December of the previous year, and allocated into three value trisects, and (c) on their average monthly return over a 11-month period beginning in June of the prior year and ending in May of the current year, and allocated into three momentum trisects.

At the intersection of the two size, three value and three momentum portfolios, we form 18 portfolios that are used for the construction of: (a) small minus big (SMB) factor, a portfolio that is long on small sized stocks and short on big sized stocks, (b) high minus low (HML) factor, a portfolio that is long on high BE/ME stocks and short on low BE/ME stocks and (c) winners minus losers (WML) factor, a portfolio that is long on winner stocks and short on loser stocks.

For the construction of the liquidity factor, all stocks at the end of June of each year are sorted on the according liquidity proxy, which is measured as an annual average of the monthly estimates for the previous calendar year, and are allocated into 10 liquidity deciles. The LIQ is a zero investment-mimicking portfolio that takes long positions on the five illiquid portfolios and short positions on the five liquid portfolios. The above procedure is repeated for all four liquidity proxies, resulting into four different liquidity factors.

It must be noted that the portfolio construction procedure for the calculation of the risk factors returns is performed with annually rebalancing frequencies, at the end of June each year, and the stocks within the portfolios are equally weighted. The annual rebalancing was adopted because the book value of the sample firms is available once a year, at the end of each calendar year, thus, making the HML factor inconsistent if intra-annual balancing is followed. Furthermore, at the end of June, we calculate the returns of all factors for the following year. The monthly returns for the 10 liquidity portfolios, less the according risk free rate, are the dependent factors used in the empirical regression models.

The effect of liquidity on asset prices is not examined only with liquidity in its original form, as estimated with the LIQ, but also, as a residual effect, by taking into account the effect of all common risk factors. In doing so, we regress the return of the LIQ against the market risk premium (MRP), the return of the size factor (SMB), the value factor $(\mathrm{HML})$ and the momentum factor $(\mathrm{WML})$ and the residuals $\left(e_{\mathrm{LIQ}}\right)$ we obtain from the regression are a measure of liquidity which is independent of any influence of the other risk factors:

$$
\begin{aligned}
\mathrm{LIQ}_{i, t}= & a+b_{\mathrm{MRP}}(\mathrm{MRP})_{t}+b_{\mathrm{SMB}}(\mathrm{SMB})_{t}+b_{\mathrm{HML}}(\mathrm{HML})_{t}+b_{\mathrm{WML}}(\mathrm{WML})_{t} \\
& +e_{\mathrm{LIQ}, t} .
\end{aligned}
$$

The above equation is estimated four times, in order to obtain the residual effect of liquidity for all four liquidity measures used. 


\subsection{Empirical model}

The first model of the empirical research examines the effect of liquidity as a residual component on asset returns:

$$
\mathrm{RP}_{i, t}-\mathrm{Rf}_{i, t}=a+b_{e \mathrm{LIQ}}\left(e_{\mathrm{LIQ}, t}\right)+e_{t},
$$

where $\mathrm{RP}_{i, t}-\mathrm{Rf}_{i, t}$ is the excess return of the 10 liquidity portfolios in month $t, e_{\mathrm{LIQ}}$ the residual measure of liquidity obtained from Eq. (3.3) and $b_{\text {eLIQ }}$ the coefficient estimation of the liquidity measure. Equation (3.4) is once again estimated four times, one for each liquidity measure. We expect the relationship between the liquidity measure $\left(e_{\mathrm{LIQ}}\right)$ and stock returns to be either positive or negative depending on the liquidity portfolio we focus each time. According to Keene \& Peterson (2007) and Chai et al. (2013) in the low liquidity portfolio, the relationship between returns and the liquidity proxy might be positive and at the high liquidity portfolios, we expect the sign of this relationship to be reversed to negative. This is due to the way we construct the liquidity-mimicking portfolio, i.e. long positions on illiquid stocks and short positions on liquid stocks. Since, the objective of the study is to examine the ability of liquidity to explain the cross-section of stock returns, the sign of the coefficients is not necessarily important.

The second empirical model examines the effect of liquidity on asset returns in its original form, i.e. as a liquidity risk factor, and after accounting for common risk factors:

$$
\begin{aligned}
\mathrm{RP}_{i, t}-\mathrm{Rf}_{i, t}= & a+b_{\mathrm{LIQ}}(\mathrm{LIQ})_{t}+b_{\mathrm{MRP}}(\mathrm{MRP})_{t}+b_{\mathrm{SMB}}(\mathrm{SMB})_{t} \\
& +b_{\mathrm{HML}}(\mathrm{HML})_{t}+b_{\mathrm{WML}}(\mathrm{WML})_{t}+e_{t},
\end{aligned}
$$

where $\mathrm{LIQ}_{t}$ is the return on the liquidity mimicking portfolio, $\mathrm{MRP}_{t}$ the market risk premium, $\mathrm{SMB}_{t}$ the return of the size factor, $\mathrm{HML}_{t}$ the return of the value factor, $\mathrm{WML}_{t}$ the return of the momentum factor in month $t$ and $b_{\mathrm{LIQ}}, b_{\mathrm{MRP}}, b_{\mathrm{SMB}}, b_{\mathrm{HML}}$ and $b_{\mathrm{WML}}$ the respective factor loadings. Equation (3.5) which is estimated for each liquidity factor separately, examines whether the inclusion of liquidity, in its original form further explains the cross section of stock returns or alters the estimated factor loadings. This is accomplished by comparing the results from Eq. (3.5) with the results from a regression that excludes the liquidity risk factor:

$$
\begin{aligned}
\mathrm{RP}_{i, t}-\mathrm{Rf}_{i, t}= & a+b_{\mathrm{MRP}}(\mathrm{MRP})_{t}+b_{\mathrm{SMB}}(\mathrm{SMB})_{t}+b_{\mathrm{HML}}(\mathrm{HML})_{t} \\
& +b_{\mathrm{WML}}(\mathrm{WML})_{t}+e_{t} .
\end{aligned}
$$

An alternative method for interpreting the intercepts of the regression models is by employing the Gibbons et al. (1989) GRS statistic to test the hypothesis Ho: $a_{i}=0 \forall i$, or simply to test the intercepts jointly. The GRS test is performed by running regression models (3.5) and (3.6) and computing the intercepts or alphas and then testing whether the alphas are jointly zero. As the estimates of intercepts 
increase in absolute value, so will the value of the GRS statistic. The equation for the GRS test is as follows:

$$
\text { GRS statistic }=\frac{(T)}{(N)} \frac{(T-N-k)}{T-k-1}\left(1+\mu_{\kappa}^{\prime} \Omega^{-1} \mu_{\kappa}\right)^{-1}\left(\hat{a}^{\prime} \hat{S}^{-1} \hat{\mathrm{a}}\right)^{\mathrm{a}},
$$

where:

$$
\begin{aligned}
T & =\text { number of observations } \\
N & =\text { number of dependent variables } \\
k & =\text { number of explanatory variables in the regression } \\
\hat{\mathrm{a}} & =N \times 1 \text { vector of estimated intercepts } \\
\hat{S} & =\text { unbiased estimates of the residual covariance matrix } \\
\mu_{\kappa} & =k \times 1 \text { vector of the factor portfolios' means } \\
\Omega & =\text { unbiased estimates of the factor portfolios' covariance matrix. }
\end{aligned}
$$

A larger value of the GRS statistic indicates that intercepts are jointly different from zero and by extension the factors of the model cannot adequately explain the variation of returns for a portfolio. A small $p$-value indicates that we can reject the null that Ho: $a_{i}=0$ for all $i$ 's.

Finally, in order to examine in detail the relationship between market liquidity and the cross section of stock returns, the tool of quantile regression is used. The specific approach was firstly put forward by Koenker \& Bassett (1978) and has been applied in many areas of financial econometrics, such as Value at Risk (Engle \& Manganelli, 1999), option pricing (Morillo, 2000), analysis of investment styles (Bassett \& Chen, 2001), testing the CAPM (Barnes \& Hughes, 2002), exchange rate risk (Gulati, 2011) and analyzing the return-volatility relationship (Allen et al. 2013).

With the use of the quantile regression approach, we can characterize particular points of the conditional distribution (upper and lower points), thus, accounting for extreme events and quantifying more efficiently for risk (Allen et al. 2013). The conditional quantile functions are estimated by minimizing an asymmetrically weighted sum of absolute errors, where the weights are functions of the quantile of interest, making the approach more robust to the presence of outliers. The conditional quantile function can be written as (Tsai, 2012)

$$
Q_{E}(\tau \mid X)=X^{\prime} \beta(\tau),
$$

where $X^{\prime}$ is a vector of the independent factors (market risk premium, size, value, momentum and liquidity risk factor) and $\beta$ the factor loadings. To obtain estimation of the conditional quantile functions, we need to solve

$$
\min _{\beta \in R^{P}} \sum_{t=1}^{n} \rho_{\tau}\left(E_{t}-X_{t}^{\prime} \beta\right)
$$

\footnotetext{
The GRS statistic has an $F$ distribution with $N$ and $T-N-K+1$ degrees of freedom under the assumption that the return of the explanatory variables are normal and the true intercepts are zero.
} 
in order to minimize the following equation:

$$
\min _{\hat{\beta}}\left[\tau \sum_{E_{t} \geq \hat{\beta} X_{t}}\left|E_{t}-\hat{\beta} X_{t}\right|+(1-\tau) \sum_{E_{t}<\hat{\beta} X_{t}}\left|E_{t}-\hat{\beta} X_{t}\right|\right],
$$

where $X_{t}^{\prime} \beta$ is an approximation to the $\tau$ th conditional quantile of the dependent variable of the model. When $\tau$ is close to zero (one), $X_{t}^{\prime} \beta$ characterizes the behavior of the dependent variable at the left (right) tail of the conditional distribution.

\section{Empirical Results}

\subsection{Descriptive statistics}

The findings from the descriptive statistics of the research variables (Table 1) support the presence of a value and momentum effect. Specifically, the HML mimicking portfolio, that is long on high $\mathrm{BE} / \mathrm{ME}$ ratio stocks and short on low $\mathrm{BE} / \mathrm{ME}$ ratio stocks, has a positive average and median value that is statistically significant at the $5 \%$ level, in line with the findings of Lu \& Hwang (2007). The average and median returns of the WML portfolio show that stocks with high past performance continue to have above average returns. Finally, the LIQ portfolio exhibited a negative return for all liquidity proxies, indicating that liquid firms outperform illiquid firms. This is in line with Chiang \& Zheng (2011) and Lu \& Hwang (2007) who find that illiquid stocks are associated with lower returns for the G7 countries and the UK, respectively, although both studies utilize an older dataset as compared to the present study. One possible explanation is that investors expect illiquid stocks to lower their prices in order to become attractive. Furthermore, the average return of the LIQ

Table 1. Descriptive statistics of research variables.

\begin{tabular}{lccccccrr}
\hline & MRP & SMB & HML & WML & LIQ $_{\mathrm{ILR}}$ & LIQ $_{\mathrm{RS}}$ & LIQ $_{\mathrm{TUR}}$ & LIQ $_{\mathrm{VTR}}$ \\
\hline Mean & -0.0007 & -0.0003 & 0.0009 & 0.0014 & -0.0046 & -0.0039 & -0.0001 & -0.0015 \\
$t$-stat & $-3.21^{* * *}$ & -0.47 & $3.11^{* * *}$ & $3.43^{* * *}$ & $-2.46^{* * *}$ & $-2.26^{* * *}$ & -0.02 & -0.86 \\
Median & 0.0060 & -0.0004 & 0.0004 & 0.0020 & -0.0042 & -0.0032 & 0.0014 & -0.0023 \\
Maximum & 0.0904 & 0.0248 & 0.0143 & 0.0187 & 0.0853 & 0.04926 & 0.0500 & 0.0722 \\
Minimum & -0.1473 & -0.0172 & -0.0176 & -0.0218 & -0.0668 & -0.0827 & -0.0656 & -0.0744 \\
Std. Dev. & 0.0433 & 0.0070 & 0.0039 & 0.0056 & 0.0247 & 0.0231 & 0.0207 & 0.0236 \\
Skewness & -0.8376 & 0.3749 & 0.0576 & -1.0703 & 0.0714 & -0.3592 & -0.2687 & 0.0299 \\
Kurtosis & 3.9439 & 3.8930 & 5.7024 & 7.3555 & 3.2333 & 3.6705 & 3.0635 & 3.3106 \\
Jarque-Bera & 27.42 & 10.08 & 54.26 & 174.67 & 0.55 & 7.16 & 1.58 & 0.74 \\
$p$-value & 0.00 & 0.01 & 0.00 & 0.00 & 0.76 & 0.03 & 0.45 & 0.69 \\
\hline
\end{tabular}

Notes: The table reports the monthly summary statistics for all factors of the research model. MRP is the market premium. SMB is the realized return on a portfolio that is long on small sized firms and short on big sized firms. HML is the realized return on the portfolio that is long on high BE/ME equity stocks and short on low BE/ME equity stocks. WML is the realized return on the portfolio that is long on winner stocks and short on loser stocks. LIQ is the realized return on the portfolio that is long on illiquid stocks short liquid stocks, for the Amihud ILR, the RS, the TUR and the volume traded proxy, respectively. *, **, *** denote significance at the $10 \%, 5 \%$ and $1 \%$ level of significance, respectively. 
Table 2. Residual effect of liquidity.

\begin{tabular}{|c|c|c|c|c|c|c|c|c|c|c|c|}
\hline \multirow[t]{2}{*}{$\mathrm{P} / \mathrm{F}$} & \multicolumn{3}{|c|}{ Illiquidity ratio } & \multicolumn{3}{|c|}{ Relative spread } & \multicolumn{2}{|c|}{ Turnover } & \multicolumn{3}{|c|}{ Volume traded } \\
\hline & $\alpha$ & $\beta e_{\mathrm{ILR}}$ & $\mathrm{Adj}-R^{2}$ & $\alpha$ & $\beta e_{\mathrm{RS}}$ & Adj- $R^{2}$ & $\beta e_{\mathrm{TUR}}$ & $\operatorname{Adj}-R^{2}$ & $\alpha$ & $\beta e_{\mathrm{VT}}$ & $\operatorname{Adj}-R^{2}$ \\
\hline 1 & $\begin{array}{c}-0.02 \\
(-2.50)^{* *}\end{array}$ & $\begin{array}{l}1.18 \\
(5.43)^{* * *}\end{array}$ & 0.09 & & $\begin{array}{c}0.89 \\
(1.87)^{*}\end{array}$ & 0.06 & $\begin{array}{l}1.00 \\
(2.24)^{* *}\end{array}$ & 0.07 & & $\begin{array}{c}0.72 \\
(2.17)^{* *}\end{array}$ & 0.05 \\
\hline 2 & & $\begin{array}{l}1.24 \\
(5.14)^{* * *}\end{array}$ & 0.12 & $\begin{array}{c}-0.01 \\
(-1.81)^{*}\end{array}$ & $\begin{array}{l}0.88 \\
(2.08)^{* *}\end{array}$ & 0.06 & $\begin{array}{c}0.81 \\
(2.05)^{* *}\end{array}$ & 0.05 & & $\begin{array}{c}0.46 \\
(1.37)\end{array}$ & 0.01 \\
\hline 3 & & $\begin{array}{l}1.03 \\
(4.70)^{* * *}\end{array}$ & 0.08 & & $\begin{array}{c}0.47 \\
(1.09)\end{array}$ & 0.01 & $\begin{array}{c}0.58 \\
(1.80)\end{array}$ & 0.02 & & $\begin{array}{c}0.51 \\
(1.51)\end{array}$ & 0.01 \\
\hline 4 & & $\begin{array}{l}1.02 \\
(4.17)^{* * *}\end{array}$ & 0.08 & & $\begin{array}{l}0.81 \\
(2.89)^{* * *}\end{array}$ & 0.05 & $\begin{array}{c}0.86 \\
(1.83)^{*}\end{array}$ & 0.04 & $\begin{array}{c}-0.01 \\
(-1.84)^{*}\end{array}$ & $\begin{array}{c}0.463 \\
(1.52)\end{array}$ & 0.01 \\
\hline 5 & & $\begin{array}{l}1.14 \\
(4.34)^{* * *}\end{array}$ & 0.09 & & $\begin{array}{c}0.58 \\
(1.74)\end{array}$ & 0.02 & $\begin{array}{c}0.74 \\
(1.59)\end{array}$ & 0.04 & & $\begin{array}{c}0.29 \\
(0.78)\end{array}$ & 0.00 \\
\hline 6 & & $\begin{array}{l}0.52 \\
(2.73)^{* *}\end{array}$ & 0.02 & & $\begin{array}{c}0.03 \\
(0.10)\end{array}$ & -0.01 & $\begin{array}{c}-0.07 \\
(-0.18)\end{array}$ & -0.01 & & $\begin{array}{c}-0.42 \\
(-1.16)\end{array}$ & 0.00 \\
\hline 7 & & $\begin{array}{c}0.33 \\
(1.57)\end{array}$ & 0.00 & & $\begin{array}{c}-0.19 \\
(-0.56)\end{array}$ & -0.00 & $\begin{array}{c}-0.07 \\
(-0.15)\end{array}$ & -0.01 & & $\begin{array}{c}-0.36 \\
(-1.06)\end{array}$ & 0.00 \\
\hline 8 & & $\begin{array}{c}0.12 \\
(0.53)\end{array}$ & -0.01 & & $\begin{array}{c}-0.38 \\
(-1.45)\end{array}$ & 0.01 & $\begin{array}{c}-0.15 \\
(-0.34)\end{array}$ & -0.01 & & $\begin{array}{c}-0.26 \\
(-0.60)\end{array}$ & -0.00 \\
\hline 9 & & $\begin{array}{c}-0.02 \\
(-0.129)\end{array}$ & -0.01 & & $\begin{array}{c}-0.29 \\
(-0.97)\end{array}$ & 0.00 & $\begin{array}{c}-0.30 \\
(-0.75)\end{array}$ & -0.00 & & $\begin{array}{l}-0.70 \\
(-2.00)^{* *}\end{array}$ & 0.02 \\
\hline 10 & & $\begin{array}{c}-0.33 \\
(-1.77)^{*}\end{array}$ & 0.01 & & $\begin{array}{l}-0.55 \\
(-2.58)^{* * *}\end{array}$ & 0.03 & $\begin{array}{c}-0.45 \\
(-0.88)\end{array}$ & 0.00 & & $\begin{array}{l}-0.85 \\
(-2.92)^{* * *}\end{array}$ & 0.05 \\
\hline
\end{tabular}

Notes: The table reports the results from the regression model examining the effect of liquidity as a residual factor. We regress the excess return $\left(\mathrm{RP}_{i, t}-\mathrm{Rf}_{i, t}\right)$ of the ten liquidity portfolios against the residual measure of liquidity $\left(e_{\mathrm{LIQ}}\right)$ obtained from Eq. (3.3) for the Amihud ILR, the RS, the TUR and the volume traded proxy, respectively. ${ }^{*}, * *$ and $* * *$ denote significance at the $10 \%, 5 \%$ and $1 \%$ level of significance, respectively.

mimicking portfolio, for the Amihud ILR and the RS, is statistically significant and takes the largest value among the other risk factors, indicating the profitability of an investment strategy based on these two liquidity ratios.

\subsection{Regression models}

The results of the first specification of the empirical model, which examines liquidity as a residual effect independent of any other factors, can be seen in Table 2. The adjusted $R^{2}$ is quite low in all regressions irrespective of the liquidity measure used, which is anticipated since we have used only one factor to explain stock returns. Thus, it appears that the LIQ alone does not necessarily play a good role in explaining stock returns. Focusing on the coefficients of the liquidity proxies, we see that we get the most statistical significant results from Amihud's illiquidity ratio, indicating that this proxy can better explain stock returns in comparison to other liquidity proxies. Furthermore, we find that the liquidity proxy coefficients have a positive sign in the low liquidity portfolios, whereas, the coefficient takes negative values as we move to the high liquidity portfolios. The change in the sign of the coefficient is a result of the way we construct the liquidity-mimicking portfolio, i.e. 


\section{P. G. Artikis}

illiquid minus liquid. Finally, it should be noted that we arrive at statistically significant results more frequently at the low and high liquidity portfolios rather than at the medium liquidity portfolios. This indicates that liquidity is perceived to be more important by market participants at the two extremes. Overall, the results are in line with Keene \& Peterson (2007) and suggest that liquidity is a priced factor that explains a certain portion of the variation of stock returns.

In Tables 3-6, we present the regression results of the liquidity effect in its original form (Eq. 3.5), when it is proxied by the Amihud ILR, RS, TUR and volume traded, respectively. Furthermore, in the last column of the above tables, we report the $R^{2}$ of Eq. (3.6), which does not include the liquidity-mimicking portfolio. Focusing, on the Amihud illiquidity proxy (Table 3) we see that liquidity is priced even after the inclusion of the other explanatory variables, which is in line with the findings of Amihud (2013).

Specifically, we witness, in the majority of the cases, an increase in the $R^{2}$ of the empirical model whenever the LIQ is included, increasing substantially its

Table 3. Regressions of excess return of ILR portfolios.

\begin{tabular}{|c|c|c|c|c|c|c|c|c|}
\hline \multirow[t]{2}{*}{$\mathrm{P} / \mathrm{F}$} & \multirow[t]{2}{*}{$\mathrm{a}$} & \multirow[t]{2}{*}{$b_{\mathrm{ILR}}$} & \multirow[t]{2}{*}{$\beta_{\mathrm{MRP}}$} & \multirow[t]{2}{*}{$\beta_{\mathrm{SMB}}$} & \multirow[t]{2}{*}{$\beta_{\mathrm{HML}}$} & \multirow[t]{2}{*}{$\beta_{\mathrm{WML}}$} & \multicolumn{2}{|c|}{$\operatorname{Adj}-R^{2}$} \\
\hline & & & & & & & with ILR & w/o ILR \\
\hline 1 & $\begin{array}{l}-0.0056 \\
(-1.72)^{*}\end{array}$ & $\begin{array}{l}1.17 \\
(7.80)^{* * *}\end{array}$ & $\begin{array}{c}1.11 \\
(12.94)^{* * *}\end{array}$ & $\begin{array}{l}-0.38 \\
(-0.59)\end{array}$ & $\begin{array}{l}-1.07 \\
(-0.97)\end{array}$ & $\begin{array}{l}-1.91 \\
(-2.73)^{* * *}\end{array}$ & 0.71 & 0.62 \\
\hline 2 & & $\begin{array}{l}1.24 \\
(7.18)^{* * *}\end{array}$ & $\begin{array}{c}0.99 \\
(10.84)^{* * *}\end{array}$ & $\begin{array}{l}-0.09 \\
(-0.11)\end{array}$ & $\begin{array}{c}0.56 \\
(0.50)\end{array}$ & $\begin{array}{l}-1.29 \\
(-1.97)^{* *}\end{array}$ & 0.68 & 0.56 \\
\hline 3 & & $\begin{array}{l}1.02 \\
(5.70)^{* * *}\end{array}$ & $\begin{array}{l}1.09 \\
(9.05)^{* * *}\end{array}$ & $\begin{array}{c}0.25 \\
(0.32)\end{array}$ & $\begin{array}{c}0.06 \\
(0.06)\end{array}$ & $\begin{array}{c}-0.87 \\
(-1.28)\end{array}$ & 0.66 & 0.58 \\
\hline 4 & & $\begin{array}{l}1.02 \\
(4.13)^{* * *}\end{array}$ & $\begin{array}{c}0.98 \\
(10.75)^{* * *}\end{array}$ & $\begin{array}{l}-0.11 \\
(-0.09)\end{array}$ & $\begin{array}{c}0.91 \\
(0.99)\end{array}$ & $\begin{array}{l}-2.08 \\
(-2.67)^{* * *}\end{array}$ & 0.62 & 0.54 \\
\hline 5 & & $\begin{array}{l}1.13 \\
(6.73)^{* * *}\end{array}$ & $\begin{array}{c}1.16 \\
(10.33)^{* * *}\end{array}$ & $\begin{array}{c}0.10 \\
(0.15)\end{array}$ & $\begin{array}{c}0.58 \\
(0.65)\end{array}$ & $\begin{array}{l}-0.45 \\
(-0.75)\end{array}$ & 0.71 & 0.62 \\
\hline 6 & & $\begin{array}{c}0.51 \\
(3.00)^{* * *}\end{array}$ & $\begin{array}{c}1.07 \\
(10.049)^{* * *}\end{array}$ & $\begin{array}{l}-0.35 \\
(-0.49)\end{array}$ & $\begin{array}{c}0.09 \\
(0.08)\end{array}$ & $\begin{array}{l}-1.93 \\
(-2.88)^{* * *}\end{array}$ & 0.63 & 0.61 \\
\hline 7 & & $\begin{array}{l}0.32 \\
(2.02)^{* *}\end{array}$ & $\begin{array}{c}1.06 \\
(10.01)^{* * *}\end{array}$ & $\begin{array}{l}-0.57 \\
(-0.85)\end{array}$ & $\begin{array}{c}1.31 \\
(1.50)\end{array}$ & $\begin{array}{l}-2.06 \\
(-3.44)^{* * *}\end{array}$ & 0.63 & 0.62 \\
\hline 8 & & $\begin{array}{c}0.11 \\
(0.65)\end{array}$ & $\begin{array}{c}1.16 \\
(10.13)^{* * *}\end{array}$ & $\begin{array}{c}0.46 \\
(0.58)\end{array}$ & $\begin{array}{l}-0.02 \\
(-0.02)\end{array}$ & $\begin{array}{l}-1.60 \\
(-2.11)^{* *}\end{array}$ & 0.61 & 0.62 \\
\hline 9 & & $\begin{array}{l}-0.02 \\
(-0.12)\end{array}$ & $\begin{array}{c}1.05 \\
(11.47)^{* * *}\end{array}$ & $\begin{array}{l}-0.71 \\
(-0.80)\end{array}$ & $\begin{array}{l}-0.01 \\
(-0.01)\end{array}$ & $\begin{array}{c}-0.009 \\
(-0.004)\end{array}$ & 0.66 & 0.67 \\
\hline 10 & & $\begin{array}{l}-0.33 \\
(-2.20)^{* *}\end{array}$ & $\begin{array}{c}1.00 \\
(16.38)^{* * *}\end{array}$ & $\begin{array}{c}0.95 \\
(1.22)\end{array}$ & $\begin{array}{l}-0.31 \\
(-0.45)\end{array}$ & $\begin{array}{l}-1.02 \\
(-1.84)^{*}\end{array}$ & 0.74 & 0.73 \\
\hline
\end{tabular}

Notes: The table reports the results from the regression model examining the effect of liquidity in its original form as a liquidity risk factor. We regress the excess return $\left(\mathrm{RP}_{i, t}-\mathrm{Rf}_{i, t}\right)$ of the ten liquidity portfolios against the return on the liquidity mimicking portfolio $\left(\mathrm{LIQ}_{\mathrm{ILR}}\right)$ based on the Amihud's illiquidity ratio, the market risk premium $\left(\mathrm{MRP}_{t}\right)$, the return of the size factor $\left(\mathrm{SMB}_{t}\right)$, the return of the value factor $\left(\mathrm{HML}_{t}\right)$, and the return of the momentum factor $\left(\mathrm{WML}_{t}\right)$. The column labeled "Adj- $R^{2}$ with ILR" gives the adjusted $R^{2}$ for a model with the liquidity risk factor $\left(\right.$ LIQ $\left._{\mathrm{ILR}}\right)$ and the column labeled "Adj- $R^{2}$ w/o ILR" gives the adjusted $R^{2}$ for a model without the liquidity proxy risk factor (LIQ $\left.\mathrm{ILR}_{\mathrm{ILR}}\right)$. $*, * *, * * *$ denotes significance at the $10 \%, 5 \%$ and $1 \%$ level of significance, respectively. 
Table 4. Regressions of excess return of RS portfolios.

\begin{tabular}{|c|c|c|c|c|c|c|c|c|}
\hline \multirow[t]{2}{*}{$\mathrm{P} / \mathrm{F}$} & \multirow[t]{2}{*}{$\alpha$} & \multirow[t]{2}{*}{$b_{\mathrm{RS}}$} & \multirow[t]{2}{*}{$\beta_{\mathrm{MRP}}$} & \multirow[t]{2}{*}{$\beta_{\mathrm{SMB}}$} & \multirow[t]{2}{*}{$\beta_{\mathrm{HML}}$} & \multirow[t]{2}{*}{$\beta_{\mathrm{WML}}$} & \multicolumn{2}{|c|}{$\operatorname{Adj}-R^{2}$} \\
\hline & & & & & & & with RS & w/o RS \\
\hline 1 & & $\begin{array}{l}0.88 \\
(4.40)^{* * *}\end{array}$ & $\begin{array}{c}0.98 \\
(10.92)^{* * *}\end{array}$ & $\begin{array}{l}2.08 \\
(3.15) * * *\end{array}$ & $\begin{array}{c}-0.53 \\
(-0.73)\end{array}$ & $\begin{array}{l}-1.69 \\
(-2.68) * * *\end{array}$ & 0.65 & 0.60 \\
\hline 2 & & $\begin{array}{l}0.88 \\
(4.94)^{* * *}\end{array}$ & $\begin{array}{c}1.02 \\
(11.42)^{* * *}\end{array}$ & $\begin{array}{l}1.70 \\
(3.02)^{* * *}\end{array}$ & $\begin{array}{c}-0.94 \\
(-1.24)\end{array}$ & $\begin{array}{l}-1.65 \\
(-2.51) * *\end{array}$ & 0.67 & 0.61 \\
\hline 3 & & $\begin{array}{l}0.46 \\
(2.17)^{* *}\end{array}$ & $\begin{array}{c}1.06 \\
(11.15)^{* * *}\end{array}$ & $\begin{array}{l}2.13 \\
(3.01)^{* * *}\end{array}$ & $\begin{array}{c}-1.60 \\
(-1.61)\end{array}$ & $\begin{array}{l}-1.82 \\
(-2.75) * * *\end{array}$ & 0.58 & 0.58 \\
\hline 4 & & $\begin{array}{l}0.80 \\
(3.97)^{* * *}\end{array}$ & $\begin{array}{l}1.02 \\
(9.55)^{* * *}\end{array}$ & $\begin{array}{c}0.38 \\
(0.65)\end{array}$ & $\begin{array}{c}0.86 \\
(1.11)\end{array}$ & $\begin{array}{l}-1.45 \\
(-2.13) * *\end{array}$ & 0.60 & 0.55 \\
\hline 5 & & $\begin{array}{l}0.58 \\
(2.41)^{* *}\end{array}$ & $\begin{array}{l}1.05 \\
(9.28)^{* * *}\end{array}$ & $\begin{array}{c}0.54 \\
(0.67)\end{array}$ & $\begin{array}{c}0.81 \\
(0.84)\end{array}$ & $\begin{array}{l}-2.20 \\
(-4.26)^{* * *}\end{array}$ & 0.60 & 0.58 \\
\hline 6 & & $\begin{array}{c}0.03 \\
(0.13)\end{array}$ & $\begin{array}{l}1.01 \\
(9.00)^{* * *}\end{array}$ & $\begin{array}{l}1.41 \\
(1.75)^{*}\end{array}$ & $\begin{array}{c}-0.37 \\
(-0.41)\end{array}$ & $\begin{array}{l}-2.79 \\
(-4.08) * * *\end{array}$ & 0.57 & 0.58 \\
\hline 7 & & $\begin{array}{l}-0.18 \\
(-0.74)\end{array}$ & $\begin{array}{l}1.06 \\
(9.05)^{* * *}\end{array}$ & $\begin{array}{l}2.02 \\
(2.40) * *\end{array}$ & $\begin{array}{c}-0.99 \\
(-1.11)\end{array}$ & $\begin{array}{l}-1.56 \\
(-2.18) * *\end{array}$ & 0.58 & 0.59 \\
\hline 8 & & $\begin{array}{l}-0.38 \\
(-2.01)^{* *}\end{array}$ & $\begin{array}{c}1.06 \\
(10.30)^{* * *}\end{array}$ & $\begin{array}{l}1.94 \\
(3.41)^{* * *}\end{array}$ & $\begin{array}{c}-0.92 \\
(-1.16)\end{array}$ & $\begin{array}{c}-1.89 \\
(-3.27)^{* * *}\end{array}$ & 0.64 & 0.63 \\
\hline 9 & & $\begin{array}{l}-0.28 \\
(-1.91)^{*}\end{array}$ & $\begin{array}{c}1.05 \\
(12.30)^{* * *}\end{array}$ & $\begin{array}{c}0.34 \\
(0.71)\end{array}$ & $\begin{array}{c}1.02 \\
(1.34)\end{array}$ & $\begin{array}{l}-0.99 \\
(-1.6928)^{*}\end{array}$ & 0.67 & 0.68 \\
\hline 10 & & $\begin{array}{l}-0.55 \\
(-3.35) * * *\end{array}$ & $\begin{array}{c}0.95 \\
(16.62)^{* * *}\end{array}$ & $\begin{array}{c}1.13 \\
(1.81)^{*}\end{array}$ & $\begin{array}{c}-0.12 \\
(-0.18)\end{array}$ & $\begin{array}{l}-1.58 \\
(-3.63) * * *\end{array}$ & 0.80 & 0.77 \\
\hline
\end{tabular}

Notes: The table reports the results from the regression model examining the effect of liquidity in its original form as a liquidity risk factor. We regress the excess return $\left(\mathrm{RP}_{i, t}-\mathrm{Rf}_{i, t}\right)$ of the 10 liquidity portfolios against the return on the liquidity mimicking portfolio $\left(\mathrm{LIQ}_{\mathrm{RS}}\right)$ based on the $\mathrm{RS}$, the market risk premium $\left(\mathrm{MRP}_{t}\right)$, the return of the size factor $\left(\mathrm{SMB}_{t}\right)$, the return of the value factor $\left(\mathrm{HML}_{t}\right)$, and the return of the momentum factor $\left(\mathrm{WML}_{t}\right)$. The column labeled "Adj-R $\mathrm{R}^{2}$ with RS" gives the adjusted $R^{2}$ for a model with the liquidity risk factor (LIQ $\mathrm{RS}_{\text {) }}$ ) and the column labeled "Adj- $R^{2}$ w/o RS" gives the adjusted $R^{2}$ for a model without the liquidity proxy risk factor (LIQ $\left.\mathrm{RS}_{\mathrm{RS}}\right)$. $*, * *$ and $* * *$ denotes significance at the $10 \%, 5 \%$ and $1 \%$ level of significance, respectively.

explanatory power, in accordance with the findings of Lu \& Hwang (2007). This indicates that the LIQ plays an important role in explaining stock returns and should not be omitted from the asset-pricing model. The coefficient of the liquiditymimicking portfolio, which is statistically significant in most cases, has large positive signs in the low liquidity portfolios, whereas at the other end of the spectrum at the high liquidity portfolios, it exhibits negative signs, which is consistent with the findings of Keene \& Peterson (2007) and Chai et al. (2013). This provides some evidence that the liquidity mimicking portfolio helps to capture the variation in stock returns related to liquidity that cannot be explained by the other factors. The coefficient of the market risk premium (MRP) is statistically significant in all cases and around 1 as expected. Finally, it should be noted that apart from the LIQ and the MRP, the loading of the momentum factor carriers a great degree of statistical significance, indicating that it contains information for the pricing of stock returns that is independent from the other two factors. 
Table 5. Regressions of excess return of turnover portfolios.

\begin{tabular}{|c|c|c|c|c|c|c|c|c|}
\hline \multirow[t]{2}{*}{$\mathrm{P} / \mathrm{F}$} & \multirow[t]{2}{*}{$\alpha$} & \multirow[t]{2}{*}{$\beta_{\mathrm{TUR}}$} & \multirow[t]{2}{*}{$\beta_{\mathrm{MRP}}$} & \multirow[t]{2}{*}{$\beta_{\mathrm{SMB}}$} & \multirow[t]{2}{*}{$\beta_{\mathrm{HML}}$} & \multirow[t]{2}{*}{$\beta_{\mathrm{WML}}$} & \multicolumn{2}{|c|}{$\operatorname{Adj}-R^{2}$} \\
\hline & & & & & & & with TUR & w/o TUR \\
\hline 1 & & $\begin{array}{l}0.99 \\
(3.71)^{* * *}\end{array}$ & $\begin{array}{l}1.21 \\
(7.78)^{* * *}\end{array}$ & $\begin{array}{c}0.76 \\
(1.46)\end{array}$ & $\begin{array}{l}-2.16 \\
(-1.98)^{* *}\end{array}$ & $\begin{array}{l}-1.69 \\
(-2.46)^{* *}\end{array}$ & 0.69 & 0.62 \\
\hline 2 & & $\begin{array}{l}0.80 \\
(3.35)^{* * *}\end{array}$ & $\begin{array}{l}1.19 \\
(8.67)^{* * *}\end{array}$ & $\begin{array}{l}1.37 \\
(2.37)^{* *}\end{array}$ & $\begin{array}{l}-1.16 \\
(-0.98)\end{array}$ & $\begin{array}{l}-0.95 \\
(-1.33)\end{array}$ & 0.63 & 0.59 \\
\hline 3 & & $\begin{array}{l}0.57 \\
(3.38)^{* * *}\end{array}$ & $\begin{array}{c}1.06 \\
(12.76)^{* * *}\end{array}$ & $\begin{array}{l}1.46 \\
(2.64) * * *\end{array}$ & $\begin{array}{l}-1.76 \\
(-1.84)^{*}\end{array}$ & $\begin{array}{l}-1.17 \\
(-2.29) * *\end{array}$ & 0.64 & 0.62 \\
\hline 4 & & $\begin{array}{l}0.85 \\
(4.03)^{* * *}\end{array}$ & $\begin{array}{c}1.40 \\
(13.51)^{* * *}\end{array}$ & $\begin{array}{l}2.11 \\
(3.06)^{* * *}\end{array}$ & $\begin{array}{l}-1.85 \\
(-1.56)\end{array}$ & $\begin{array}{l}-1.11 \\
(-1.74)^{*}\end{array}$ & 0.65 & 0.61 \\
\hline 5 & & $\begin{array}{l}0.73 \\
(2.84)^{* * *}\end{array}$ & $\begin{array}{l}1.21 \\
(7.71)^{* * *}\end{array}$ & $\begin{array}{c}0.85 \\
(1.29)\end{array}$ & $\begin{array}{c}1.63 \\
(1.54)\end{array}$ & $\begin{array}{c}-2.11 \\
(-3.27)^{* * *}\end{array}$ & 0.67 & 0.63 \\
\hline 6 & $\begin{array}{c}-0.0054 \\
(-1.652)^{*}\end{array}$ & $\begin{array}{c}-0.06 \\
(-0.39)\end{array}$ & $\begin{array}{c}1.25 \\
(15.03)^{* * *}\end{array}$ & $\begin{array}{l}1.86 \\
(3.35)^{* * *}\end{array}$ & $\begin{array}{l}-1.16 \\
(-1.21)\end{array}$ & $\begin{array}{c}0.17 \\
(0.33)\end{array}$ & 0.71 & 0.72 \\
\hline 7 & & $\begin{array}{c}-0.069 \\
(-0.25)\end{array}$ & $\begin{array}{l}1.14 \\
(7.09)^{* * *}\end{array}$ & $\begin{array}{l}1.39 \\
(2.54)^{* *}\end{array}$ & $\begin{array}{c}-0.19 \\
(-0.16)\end{array}$ & $\begin{array}{c}-1.66 \\
(-2.63) * * *\end{array}$ & 0.68 & 0.68 \\
\hline 8 & & $\begin{array}{c}-0.14 \\
(-0.56)\end{array}$ & $\begin{array}{l}1.20 \\
(7.95)^{* * *}\end{array}$ & $\begin{array}{c}0.67 \\
(1.20)\end{array}$ & $\begin{array}{c}-0.60 \\
(-0.54)\end{array}$ & $\begin{array}{c}-0.97 \\
(-1.35)\end{array}$ & 0.69 & 0.70 \\
\hline 9 & & $\begin{array}{c}-0.29 \\
(-1.28)\end{array}$ & $\begin{array}{l}1.08 \\
(8.63)^{* * *}\end{array}$ & $\begin{array}{c}0.93 \\
(1.59)\end{array}$ & $\begin{array}{c}0.09 \\
(0.08)\end{array}$ & $\begin{array}{l}-2.38 \\
(-3.70) * * *\end{array}$ & 0.69 & 0.69 \\
\hline 10 & & $\begin{array}{c}-0.44 \\
(-1.51)\end{array}$ & $\begin{array}{l}1.38 \\
(6.89)^{* * *}\end{array}$ & $\begin{array}{l}1.70 \\
(2.29)^{* *}\end{array}$ & $\begin{array}{l}-3.44 \\
(-2.27)^{* *}\end{array}$ & $\begin{array}{l}-2.20 \\
(-2.20)^{* *}\end{array}$ & 0.71 & 0.71 \\
\hline
\end{tabular}

Notes: The table reports the results from the regression model examining the effect of liquidity in its original form as a liquidity risk factor. We regress the excess return $\left(\mathrm{RP}_{i, t}-\mathrm{Rf}_{i, t}\right)$ of the 10 liquidity portfolios against the return on the liquidity mimicking portfolio $\left(\mathrm{LIQ}_{\mathrm{TUR}}\right)$ based on the TUB, the market risk premium $\left(\mathrm{MRP}_{t}\right)$, the return of the size factor $\left(\mathrm{SMB}_{t}\right)$, the return of the value factor $\left(\mathrm{HML}_{t}\right)$, and the return of the momentum factor $\left(\mathrm{WML}_{t}\right)$. The column labeled "Adj- $R^{2}$ with TUR" gives the adjusted $R^{2}$ for a model with the liquidity risk factor ( $\mathrm{LIQ}_{\mathrm{TUR}}$ ) and the column labeled "Adj- $R^{2}$ w/o TUR" gives the adjusted $R^{2}$ for a model without the liquidity proxy risk factor $\left(\mathrm{LIQ}_{\mathrm{TUR}}\right) .{ }^{*},{ }^{* *}$ and $* * *$ denotes significance at the $10 \%, 5 \%$ and $1 \%$ level of significance, respectively.

The results from the RS risk factor are quite similar (Table 4) in terms of the statistical significance of the liquidity factor coefficient, the increase in the explanatory power of the model when the LIQ is included and the importance of the market risk premium, thus, corroborating the initial findings.

Furthermore, the importance of the momentum factor for explaining stock returns is exhibited, since it carries a statistical significant coefficient in all liquiditybased portfolios.

The initial findings are further validated when we use in the empirical model the TUR risk factor (Table 5). The LIQ exhibits the same pattern, although its statistical significance remains only at the low and medium liquidity portfolios.

Finally, the results from the volume traded risk factor are presented in Table 6. The coefficient of the liquidity factor remains unchanged as previously, as far as the pattern is concerned. Once again, the statistically significant coefficients are in the low and high liquidity portfolios rather than in the medium liquidity portfolios and we witness an increase in the explanatory power of the model when we include the 
Table 6. Regressions of excess return of volume traded portfolios.

\begin{tabular}{|c|c|c|c|c|c|c|c|c|}
\hline \multirow[t]{2}{*}{$\mathrm{P} / \mathrm{F}$} & \multirow[t]{2}{*}{$\alpha$} & \multirow[t]{2}{*}{$\beta_{\mathrm{VTR}}$} & \multirow[t]{2}{*}{$\beta_{\mathrm{MRP}}$} & \multirow[t]{2}{*}{$\beta_{\mathrm{SMB}}$} & \multirow[t]{2}{*}{$\beta_{\mathrm{HML}}$} & \multirow[t]{2}{*}{$\beta_{\mathrm{WML}}$} & \multicolumn{2}{|c|}{$\operatorname{Adj}-R^{2}$} \\
\hline & & & & & & & with VTR & w/o VTR \\
\hline 1 & & $\begin{array}{l}0.72 \\
(3.40)^{* * *}\end{array}$ & $\begin{array}{l}0.91 \\
(9.56)^{* * *}\end{array}$ & $\begin{array}{l}1.49 \\
(2.62)^{* * *}\end{array}$ & $\begin{array}{l}-0.88 \\
(-1.42)\end{array}$ & $\begin{array}{l}-2.25 \\
(-3.53) * * *\end{array}$ & 0.61 & 0.57 \\
\hline 2 & & $\begin{array}{l}0.46 \\
(2.17)^{* *}\end{array}$ & $\begin{array}{c}1.01 \\
(10.36)^{* * *}\end{array}$ & $\begin{array}{l}2.49 \\
(4.05) * * *\end{array}$ & $\begin{array}{l}-1.76 \\
(-1.97)^{* *}\end{array}$ & $\begin{array}{l}-1.28 \\
(-1.72)^{*}\end{array}$ & 0.56 & 0.56 \\
\hline 3 & & $\begin{array}{l}0.51 \\
(2.15) * *\end{array}$ & $\begin{array}{c}1.06 \\
(11.04)^{* * *}\end{array}$ & $\begin{array}{l}1.99 \\
(3.07) * * *\end{array}$ & $\begin{array}{c}-0.30 \\
(-0.38)\end{array}$ & $\begin{array}{c}-1.56 \\
(-2.45) * *\end{array}$ & 0.57 & 0.56 \\
\hline 4 & & $\begin{array}{c}0.42 \\
(1.93)^{*}\end{array}$ & $\begin{array}{c}1.01 \\
(10.35)^{* * *}\end{array}$ & $\begin{array}{l}1.66 \\
(3.05) * * *\end{array}$ & $\begin{array}{c}-0.85 \\
(-1.02)\end{array}$ & $\begin{array}{l}-1.77 \\
(-3.24) * * *\end{array}$ & 0.55 & 0.55 \\
\hline 5 & & $\begin{array}{c}0.29 \\
(1.04)\end{array}$ & $\begin{array}{c}1.09 \\
(11.06)^{* * *}\end{array}$ & $\begin{array}{l}1.68 \\
(2.17)^{* *}\end{array}$ & $\begin{array}{c}0.16 \\
(0.19)\end{array}$ & $\begin{array}{l}-2.49 \\
(-4.08) * * *\end{array}$ & 0.60 & 0.60 \\
\hline 6 & & $\begin{array}{c}-0.42 \\
(-1.59)\end{array}$ & $\begin{array}{l}1.08 \\
(9.71)^{* * *}\end{array}$ & $\begin{array}{l}3.38 \\
(4.57) * * *\end{array}$ & $\begin{array}{l}-1.74 \\
(-1.78)^{*}\end{array}$ & $\begin{array}{l}-2.60 \\
(-3.62) * * *\end{array}$ & 0.61 & 0.61 \\
\hline 7 & & $\begin{array}{c}-0.35 \\
(-1.15)\end{array}$ & $\begin{array}{l}0.98 \\
(9.60)^{* * *}\end{array}$ & $\begin{array}{l}2.09 \\
(2.21)^{* *}\end{array}$ & $\begin{array}{c}-0.93 \\
(-1.006)\end{array}$ & $\begin{array}{c}-2.21 \\
(-3.59) * * *\end{array}$ & 0.59 & 0.59 \\
\hline 8 & & $\begin{array}{c}-0.25 \\
(-1.21)\end{array}$ & $\begin{array}{l}1.08 \\
(9.06)^{* * *}\end{array}$ & $\begin{array}{c}0.29 \\
(0.49)\end{array}$ & $\begin{array}{c}0.82 \\
(0.95)\end{array}$ & $\begin{array}{l}-2.50 \\
(-4.15) * * *\end{array}$ & 0.65 & 0.65 \\
\hline 9 & & $\begin{array}{l}-0.69 \\
(-3.39) * * *\end{array}$ & $\begin{array}{c}1.008 \\
(11.38)^{* * *}\end{array}$ & $\begin{array}{l}1.72 \\
(2.98) * * *\end{array}$ & $\begin{array}{c}-0.93 \\
(-1.28)\end{array}$ & $\begin{array}{l}-1.80 \\
(-3.36) * * *\end{array}$ & 0.70 & 0.67 \\
\hline 10 & & $\begin{array}{l}-0.85 \\
(-3.65) * * *\end{array}$ & $\begin{array}{c}0.93 \\
(12.74)^{* * *}\end{array}$ & $\begin{array}{l}1.83 \\
(2.36)^{* *}\end{array}$ & $\begin{array}{c}-0.84 \\
(-1.13)\end{array}$ & $\begin{array}{l}-0.25 \\
(-0.47)\end{array}$ & 0.79 & 0.74 \\
\hline
\end{tabular}

Notes: The table reports the results from the regression model examining the effect of liquidity in its original form as a liquidity risk factor. We regress the excess return $\left(\mathrm{RP}_{i, t}-\mathrm{Rf}_{i, t}\right)$ of the ten liquidity portfolios against the return on the liquidity mimicking portfolio $\left(\mathrm{LIQ}_{\mathrm{VTR}}\right)$ based on the volume traded, the market risk premium $\left(\mathrm{MRP}_{t}\right)$, the return of the size factor $\left(\mathrm{SMB}_{t}\right)$, the return of the value factor $\left(\mathrm{HML}_{t}\right)$, and the return of the momentum factor $\left(\mathrm{WML}_{t}\right)$. The column labeled "Adj- $R^{2}$ with VTR" gives the adjusted $R^{2}$ for a model with the liquidity risk factor (LIQ $\mathrm{VTR}_{\mathrm{VR}}$ ) and the column labeled "Adj- $R^{2}$ w/o VTR" gives the adjusted $R^{2}$ for a model without the liquidity proxy risk factor $\left(\mathrm{LIQ}_{\mathrm{VTR}}\right)$. $*, * *$ and ${ }^{* * *}$ denotes significance at the $10 \%, 5 \%$ and $1 \%$ level of significance, respectively.

liquidity factor, while the other two important factors than should not be omitted from the asset pricing model are the market risk premium and the momentum factor.

Overall the results from the above regressions document the importance of the LIQ in explaining stock returns, even after controlling for the well known risk factors, in line with Keene \& Peterson (2007) and Lu \& Hwang (2007). Furthermore, the significance of liquidity is concentrated mainly in the high and low liquidity portfolios, which is in line with the findings of Foran et al. (2014), who exhibit that liquidity risk mimicking portfolios have a statistically significant return premium among the extreme ends of liquidity risk. Finally, the results show that the momentum factor remains significant in all four liquidity proxy regressions, which is similar to findings of Foran et al. (2014), who show that when a momentum factor is included in the analysis, the liquidity premia remain significant.

The GRS statistics are shown in Table 7 for the four liquidity proxies and empirical models (5) with the liquidity proxy and (6) without the liquidity proxy. From the comparison of the two empirical models, it is evident that the inclusion of 
Table 7. Regressions of excess return of volume traded portfolios.

\begin{tabular}{lccc}
\hline Model & GRS F-Stat & GRS $p$-val & Absolute alpha \\
\hline 4 Factor without ILR & 1.41 & 0.11 & 0.00376 \\
4 Factor with ILR & 1.09 & 0.33 & 0.00569 \\
4 Factor without RS & 1.47 & 0.08 & 0.00199 \\
4 Factor with RS & 0.97 & 0.44 & 0.00121 \\
4 Factor without TUR & 2.49 & 0.00 & 0.00214 \\
4 Factor with TUR & 2.33 & 0.00 & 0.00235 \\
4 Factor without VTR & 2.35 & 0.00 & 0.00157 \\
4 Factor with VTR & 2.17 & 0.00 & 0.00142 \\
\hline
\end{tabular}

Notes: The table shows the Gibbons et al. (1989) F-statistic (GRS) for testing the null hypothesis that model intercepts are jointly equal to zero for all 10 liquidity portfolios. GRS $p$-val is the $p$-value of the GRS $F$-test. Absolute alpha is the mean of the absolute value of model intercepts of the 10 liquidity portfolios.

Table 8. Quantile regressions of excess return of ILR portfolios at the 0.05 th quantile.

\begin{tabular}{|c|c|c|c|c|c|c|c|c|}
\hline \multirow{2}{*}{$\mathrm{P} / \mathrm{F}$} & \multirow[t]{2}{*}{$a$} & \multirow[t]{2}{*}{$b_{\mathrm{ILR}}$} & \multirow[t]{2}{*}{$\beta_{\mathrm{MRP}}$} & \multirow[t]{2}{*}{$\beta_{\mathrm{SMB}}$} & \multirow[t]{2}{*}{$\beta_{\mathrm{HML}}$} & \multirow[t]{2}{*}{$\beta_{\mathrm{WML}}$} & \multicolumn{2}{|c|}{$\operatorname{Adj}-R^{2}$} \\
\hline & & & & & & & with ILR & w/o ILR \\
\hline 1 & $\begin{array}{c}-0.074 \\
(-11.98)^{* * *}\end{array}$ & $\begin{array}{c}0.72 \\
(1.94)^{*}\end{array}$ & $\begin{array}{c}1.46 \\
(10.64)^{* * *}\end{array}$ & $\begin{array}{c}0.97 \\
(0.71)\end{array}$ & $\begin{array}{l}-1.58 \\
(-1.17)\end{array}$ & $\begin{array}{l}-3.34 \\
(-4.04)^{* * *}\end{array}$ & 0.56 & 0.53 \\
\hline 2 & $\begin{array}{l}-0.059 \\
(-8.68) * * *\end{array}$ & $\begin{array}{l}1.19 \\
(4.26)^{* * *}\end{array}$ & $\begin{array}{c}0.99 \\
(13.28)^{* * *}\end{array}$ & $\begin{array}{c}-0.23 \\
(-0.15)\end{array}$ & $\begin{array}{c}0.08 \\
(0.08)\end{array}$ & $\begin{array}{c}-1.32 \\
(-1.57)\end{array}$ & 0.48 & 0.40 \\
\hline 3 & $\begin{array}{c}-0.061 \\
(-8.74)^{* * *}\end{array}$ & $\begin{array}{l}0.66 \\
(3.05)^{* * *}\end{array}$ & $\begin{array}{c}0.99 \\
(11.58)^{* * *}\end{array}$ & $\begin{array}{c}-1.58 \\
(-1.92)^{*}\end{array}$ & $\begin{array}{c}-0.21 \\
(-0.15)\end{array}$ & $\begin{array}{l}-0.28 \\
(-0.46)\end{array}$ & 0.45 & 0.43 \\
\hline 4 & $\begin{array}{c}-0.057 \\
(-7.45) * * *\end{array}$ & $\begin{array}{l}1.94 \\
(3.79)^{* * *}\end{array}$ & $\begin{array}{c}1.02 \\
(7.61)^{* * *}\end{array}$ & $\begin{array}{l}-3.00 \\
(-2.84)^{* * *}\end{array}$ & $\begin{array}{c}2.77 \\
(1.92)^{*}\end{array}$ & $\begin{array}{l}-1.50 \\
(-2.56) * *\end{array}$ & 0.47 & 0.39 \\
\hline 5 & $\begin{array}{r}-0.057 \\
(-11.53)\end{array}$ & $\begin{array}{l}1.14 \\
(4.21)^{* * *}\end{array}$ & $\begin{array}{c}1.21 \\
(14.34)^{* * *}\end{array}$ & $\begin{array}{c}0.44 \\
(0.43)\end{array}$ & $\begin{array}{c}0.41 \\
(0.29)\end{array}$ & $\begin{array}{c}0.32 \\
(0.38)\end{array}$ & 0.71 & 0.46 \\
\hline 6 & $\begin{array}{l}-0.069 \\
(-7.89)^{* * *}\end{array}$ & $\begin{array}{c}0.87 \\
(1.80)^{*}\end{array}$ & $\begin{array}{c}1.31 \\
(6.59)^{* * *}\end{array}$ & $\begin{array}{c}-1.53 \\
(-1.00)\end{array}$ & $\begin{array}{c}1.50 \\
(1.53)\end{array}$ & $\begin{array}{l}-2.15 \\
(-2.11) * *\end{array}$ & 0.51 & 0.48 \\
\hline 7 & $\begin{array}{c}-0.067 \\
(-8.90)^{* * *}\end{array}$ & $\begin{array}{c}0.23 \\
(0.85)\end{array}$ & $\begin{array}{l}1.45 \\
(9.24)^{* * *}\end{array}$ & $\begin{array}{c}-1.18 \\
(-0.86)\end{array}$ & $\begin{array}{c}3.59 \\
(1.72)^{*}\end{array}$ & $\begin{array}{l}-1.89 \\
(-1.13)\end{array}$ & 0.52 & 0.52 \\
\hline 8 & $\begin{array}{c}-0.079 \\
(-5.80) * * *\end{array}$ & $\begin{array}{l}-0.67 \\
(-1.78)^{*}\end{array}$ & $\begin{array}{l}1.27 \\
(3.94)^{* * *}\end{array}$ & $\begin{array}{c}1.18 \\
(0.96)\end{array}$ & $\begin{array}{l}-0.33 \\
(-0.14)\end{array}$ & $\begin{array}{l}-1.65 \\
(-2.20)^{*}\end{array}$ & 0.43 & 0.43 \\
\hline 9 & $\begin{array}{c}-0.066 \\
(-6.12)^{* * *}\end{array}$ & $\begin{array}{l}-0.41 \\
(-2.01)^{* *}\end{array}$ & $\begin{array}{l}1.34 \\
(4.28) * * *\end{array}$ & $\begin{array}{c}-0.81 \\
(-1.18)\end{array}$ & $\begin{array}{c}-0.78 \\
(-0.72)\end{array}$ & $\begin{array}{c}-0.76 \\
(-0.48)\end{array}$ & 0.50 & 0.49 \\
\hline 10 & $\begin{array}{c}-0.043 \\
(-5.55)^{* * *}\end{array}$ & $\begin{array}{l}-0.22 \\
(-0.45)^{* *}\end{array}$ & $\begin{array}{c}1.14 \\
(15.36) * * *\end{array}$ & $\begin{array}{c}0.10 \\
(0.06)\end{array}$ & $\begin{array}{c}0.27 \\
(0.21)\end{array}$ & $\begin{array}{l}-0.75 \\
(-1.07)^{*}\end{array}$ & 0.58 & 0.58 \\
\hline
\end{tabular}

Notes: The table reports the results from the quantile regressions examining the effect of liquidity in its original form as a LIQ at the 0.05 th quantile. We regress the excess return $\left(\mathrm{RP}_{i, t}-\mathrm{Rf}_{i, t}\right)$ of the ten liquidity portfolios against the return on the liquidity mimicking portfolio $\left(\mathrm{LIQ}_{\mathrm{ILR}}\right)$ based on the Amihud's illiquidity ratio, the market risk premium $\left(\mathrm{MRP}_{t}\right)$, the return of the size factor $\left(\mathrm{SMB}_{t}\right)$, the return of the value factor $\left(\mathrm{HML}_{t}\right)$, and the return of the momentum factor $\left(\mathrm{WML}_{t}\right)$. The column labeled "Adj- $R^{2}$ with ILR" gives the adjusted $R^{2}$ for a model with the LIQ ILR $_{\text {IL }}$ and the column labeled "Adj- $R^{2} \mathrm{w} / \mathrm{o}$ ILR" gives the adjusted $R^{2}$ for a model without the liquidity proxy risk factor $\left(\mathrm{LIQ}_{\mathrm{ILR}}\right)$. *, ** and *** denotes significance at the $10 \%, 5 \%$ and $1 \%$ level of significance, respectively. 
the liquidity proxy reduces the value of the GRS F-statistic, indicating that the alpha coefficients are closer to zero in a statistical sense. However, only when we include in the four factor model either the Amihud ILR or the RS, the alpha coefficients of the empirical models are jointly statistically significant equal to zero, indicating that these two liquidity proxies better explain future stock returns.

In order to test the relationship between liquidity and stock returns in more detail, we performed for Eqs. (3.5) and (3.6) quantile regressions at various points of our total sample. The objective was to observe any changes that we may have in the statistical significance of the research model variables. Due to space considerations detailed results from the 0.05 th and 0.90 th quantiles (Tables 8 and 9, respectively) are reported only for the Amihud ILR, which has proven to explain better the returns of the liquidity portfolios.

At the 0.05th quantile regressions, the coefficient of the ILR portfolios (Table 8) exhibits a quite similar pattern with the one from the OLS regressions (Table 3), in terms of sign, magnitude and statistical significance. Specifically, as we can see from

Table 9. Quantile regressions of excess return of ILR portfolios at the 0.9th quantile.

\begin{tabular}{|c|c|c|c|c|c|c|c|c|}
\hline \multirow[t]{2}{*}{$\mathrm{P} / \mathrm{F}$} & \multirow[t]{2}{*}{$a$} & \multirow[t]{2}{*}{$b_{\mathrm{ILR}}$} & \multirow[t]{2}{*}{$\beta_{\mathrm{MRP}}$} & \multirow[t]{2}{*}{$\beta_{\mathrm{SMB}}$} & \multirow[t]{2}{*}{$\beta_{\mathrm{HML}}$} & \multirow[t]{2}{*}{$\beta_{\mathrm{WML}}$} & \multicolumn{2}{|c|}{$\operatorname{Adj}-R^{2}$} \\
\hline & & & & & & & with ILR & w/o ILR \\
\hline 1 & $\begin{array}{l}0.042 \\
(8.66)^{* * *}\end{array}$ & $\begin{array}{l}1.42 \\
(6.37)^{* * *}\end{array}$ & $\begin{array}{l}1.03 \\
(6.86)^{* * *}\end{array}$ & $\begin{array}{c}0.38 \\
(0.57)\end{array}$ & $\begin{array}{c}-2.31 \\
(-1.43)\end{array}$ & $\begin{array}{l}-2.20 \\
(-2.66) * * *\end{array}$ & 0.50 & 0.38 \\
\hline 2 & $\begin{array}{c}0.040 \\
(10.03)^{* * *}\end{array}$ & $\begin{array}{l}1.31 \\
(7.60)^{* * *}\end{array}$ & $\begin{array}{l}0.83 \\
(6.44)^{* * *}\end{array}$ & $\begin{array}{c}0.27 \\
(0.29)\end{array}$ & $\begin{array}{c}-0.18 \\
(-0.11)\end{array}$ & $\begin{array}{l}-1.64 \\
(-1.87)^{*}\end{array}$ & 0.46 & 0.30 \\
\hline 3 & $\begin{array}{l}0.048 \\
(8.60)^{* * *}\end{array}$ & $\begin{array}{l}0.86 \\
(2.52)^{* *}\end{array}$ & $\begin{array}{l}1.00 \\
(7.93)^{* * *}\end{array}$ & $\begin{array}{l}1.24 \\
(1.08)^{*}\end{array}$ & $\begin{array}{c}0.15 \\
(0.09)\end{array}$ & $\begin{array}{l}-2.10 \\
(-1.64)\end{array}$ & 0.44 & 0.39 \\
\hline 4 & $\begin{array}{l}0.046 \\
(6.11)^{* * *}\end{array}$ & $\begin{array}{c}0.49 \\
(0.19)\end{array}$ & $\begin{array}{l}0.87 \\
(3.90)^{* * *}\end{array}$ & $\begin{array}{c}0.72 \\
(0.62)\end{array}$ & $\begin{array}{l}1.05 \\
(0.80)\end{array}$ & $\begin{array}{l}-3.17 \\
(-2.40)^{* *}\end{array}$ & 0.35 & 0.33 \\
\hline 5 & $\begin{array}{c}0.039 \\
(9.56)\end{array}$ & $\begin{array}{l}1.03 \\
(7.68)^{* * *}\end{array}$ & $\begin{array}{c}1.10 \\
(11.15)^{* * *}\end{array}$ & $\begin{array}{c}0.13 \\
(0.24)\end{array}$ & $\begin{array}{c}0.58 \\
(0.75)\end{array}$ & $\begin{array}{l}-2.02 \\
(-2.76)\end{array}$ & 0.52 & 0.40 \\
\hline 6 & $\begin{array}{l}0.045 \\
(9.57)^{* * *}\end{array}$ & $\begin{array}{c}0.33 \\
(1.22)\end{array}$ & $\begin{array}{l}0.69 \\
(4.76)^{* * *}\end{array}$ & $\begin{array}{c}-0.98 \\
(-0.71)\end{array}$ & $\begin{array}{c}-0.30 \\
(-0.20)\end{array}$ & $\begin{array}{l}-3.10 \\
(-4.47)^{* * *}\end{array}$ & 0.37 & 0.37 \\
\hline 7 & $\begin{array}{c}0.043 \\
(11.24)^{* * *}\end{array}$ & $\begin{array}{l}0.55 \\
(3.18)^{* * *}\end{array}$ & $\begin{array}{c}0.91 \\
(6.26)^{* * *}\end{array}$ & $\begin{array}{c}-1.36 \\
(-1.66)^{*}\end{array}$ & $\begin{array}{c}0.56 \\
(0.72)^{*}\end{array}$ & $\begin{array}{l}-1.91 \\
(-4.56) * * *\end{array}$ & 0.36 & 0.35 \\
\hline 8 & $\begin{array}{l}0.044 \\
(9.20)^{* * *}\end{array}$ & $\begin{array}{c}0.07 \\
(0.36)^{*}\end{array}$ & $\begin{array}{l}0.90 \\
(6.42)^{* * *}\end{array}$ & $\begin{array}{c}1.14 \\
(1.80)^{*}\end{array}$ & $\begin{array}{c}-0.56 \\
(-0.38)\end{array}$ & $\begin{array}{l}-1.82 \\
(-2.01)^{* *}\end{array}$ & 0.34 & 0.34 \\
\hline 9 & $\begin{array}{l}0.034 \\
(7.71)^{* * *}\end{array}$ & $\begin{array}{l}-0.17 \\
(-0.87)\end{array}$ & $\begin{array}{l}0.93 \\
(9.52)^{* * *}\end{array}$ & $\begin{array}{c}0.65 \\
(0.76)\end{array}$ & $\begin{array}{c}-1.14 \\
(-0.89)\end{array}$ & $\begin{array}{l}-1.34 \\
(-1.34)\end{array}$ & 0.39 & 0.38 \\
\hline 10 & $\begin{array}{c}0.021 \\
(8.38)^{* * *}\end{array}$ & $\begin{array}{c}-0.24 \\
(-3.12) * * *\end{array}$ & $\begin{array}{c}0.90 \\
(11.31)^{* * *}\end{array}$ & $\begin{array}{c}0.21 \\
(0.40)\end{array}$ & $\begin{array}{c}-0.09 \\
(-0.09)\end{array}$ & $\begin{array}{c}-0.99 \\
(-1.64)\end{array}$ & 0.41 & 0.38 \\
\hline
\end{tabular}

Notes: The table reports the results from the quantile regression model examining the effect of liquidity in its original form as a LIQ at the 0.9 th quantile. We regress the excess return $\left(\mathrm{RP}_{i, t}-\mathrm{Rf}_{i, t}\right)$ of the 10

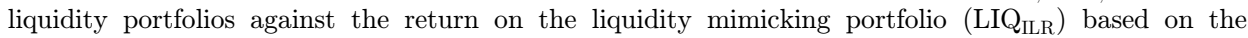
Amihud's illiquidity ratio, the market risk premium $\left(\mathrm{MRP}_{t}\right)$, the return of the size factor $\left(\mathrm{SMB}_{t}\right)$, the return of the value factor $\left(\mathrm{HML}_{t}\right)$, and the return of the momentum factor $\left(\mathrm{WML}_{t}\right)$. The column labeled "Adj- $R^{2}$ with ILR" gives the adjusted $R^{2}$ for a model with the LIQ $\mathrm{ILR}_{\mathrm{LR}}$ and the column labeled "Adj- $R^{2} \mathrm{w} /$ o ILR" gives the adjusted $R^{2}$ for a model without the liquidity proxy risk factor (LIQ $\left.\mathrm{ILR}_{\text {IL }}\right){ }^{*}$, ** and *** denotes significance at the $10 \%, 5 \%$ and $1 \%$ level of significance, respectively. 
Table 8 , the coefficient is statistical significant in the majority of the liquidity portfolios (80\%) and it reveals a positive relationship at the low end of the spectrum (illiquid portfolios), whereas at the other end (liquid portfolios), the relationship turns out to be negative. By focusing on the 0.9th quantile (Table 9), we see that the relationship between the returns of the liquidity portfolios and the LIQ exhibit the same pattern; most coefficients $(80 \%)$ are statistically significant and the sign changes from positive to negative when we move from the illiquid to the liquid portfolios. The findings indicate that the relationship between the LIQ and stock returns is stable and does not vary even over extreme quantiles.

\section{Conclusions}

The objective of the present paper was to examine the role of liquidity in asset pricing after controlling for the well-known risk factors and through the use of OLS timeseries regressions and quantile regressions. Previous studies in the area focus only on the traditional approach of OLS regressions and do not address fully the relationship between liquidity and the Fama and French factors and momentum in the UK stock market. Four widely used liquidity proxies, based on low-frequency data, are employed in the analysis, in order to investigate the liquidity phenomenon either as a residual effect, free of any other influence, or in its original form as an additional risk factor.

The findings show that liquid firms earn on average larger returns than illiquid in UK for the time period of the research, in line with the findings of Chiang \& Zheng (2011) for the G7 countries. This reveals that investors in order to be willing to buy illiquid stocks expect them to have lower their prices.

Liquidity in its residual form explains a certain portion of the shared variation of stock returns. Amihud's ILR proves to be more useful in explaining stock returns among the liquidity proxies examined. The results of the empirical models show a change in the sign of the liquidity proxy coefficients, from positive to negative, as we move from the low to the high liquidity portfolios, which is in line with the findings of Keene \& Peterson (2007) for the US and the hypothesis of Chai et al. (2013).

Liquidity in its original form is a systematic pricing factor for stocks and explains a significant portion of the variation in stock returns, even after the inclusion of the other explanatory variables, such as the market risk premium, size, value and the momentum risk factor, which is in favor to the findings of Amihud et al. (2013). Liquidity risk is an extra dimension that portfolio and risk managers should consider when they either construct their portfolios or when they decompose the total risk of the portfolios into various factors. Investors need to incorporate in their choices between different socks and/or portfolios liquidity preferences.

The inclusion of liquidity in the asset pricing models, and in particular of the Amihud ILR and the RS, increases significantly their explanatory power and the alpha coefficients are jointly closer to zero in a statistical sense. The analysis from the quantile regressions shows that the market risk premium remains the most 
important risk factor and should never be omitted. Furthermore, the LIQ remains important in all quantiles, exhibiting a similar pattern and by absorbing information contained in the size and value risk factor and remaining independent of the information content of the momentum factor.

\section{References}

V. V. Acharya \& L. H. Pedersen (2005) Asset pricing with liquidity risk, Journal of Financial Economics 77, 375-410.

V. V. Acharya, Y. Amihud \& S. T. Bharath (2013) Liquidity risk of corporate bond returns: Conditional approach, Journal of Financial Economics 110 (2), 358-386.

D. Allen, A. Singh, R. Powell, M. McAleer, J. Taylor and L. Thomas (2013) Return-Volatility Relationship: Insights from Linear and Non-Linear Quantile Regression, Available at SSRN 2253685.

Y. Amihud (2002) Illiquidity and stock returns: Cross-section and time-series effects, Journal of Financial Markets 5, 31-56.

Y. Amihud \& H. Mendelson (1986) Asset pricing and the bid-ask spread, Journal of Financial Economics 17, 223-249.

Y. Amihud, A. Hameed, W. Kang \& H. Zhang (2013) The illiquidity premium: International evidence, Available at SSRN 2191949.

D. Anderson, P. Clarkson \& S. Moran (1997) The association between information, liquidity, and two stock market anomalies, the size effect and seasonalities in equity returns, Accounting Research Journal 10, 6-19.

M. L. Barnes \& A. T. W. Hughes (2002) A quantile regression analysis of the cross section of stock market returns, Available at SSRN: http://ssrn.com/abstract=458522 or http:// dx.doi.org/10.2139/ssrn.458522.

G. Bassett \& H.-L. Chen (2001) Quantile style: Return-based attribution using regression quantiles, Empiral Economics 26 (1), 293-305.

G. Bekaert, C. Harvey \& C. Lundblad (2007) Liquidity and expected returns: Lessons from emerging markets, Review of Financial Studies 20, 1783-1831.

M. J. Brennan \& A. Subrahmanyam (1996) Market microstructure and asset pricing: On the compensation for illiquidity in stock returns, Journal of Financial Economics 41, 441-464.

M. J. Brennan, T. Chordia, A. Subrahmanyam \& Q. Tong (2012) Sell-order liquidity and the cross-section of expected stock returns, Journal of Financial Economics 105 (3), $523-541$.

M. Brennan, S. W. Huh \& A. Subrahmanyam (2013) An analysis of the Amihud illiquidity premium, Review of Asset Pricing Studies 3 (1), 133-176.

M. K. Brunnermeier (2008) Deciphering the liquidity and credit crunch 2007-08. National Bureau of Economic Research.

C. Cao \& L. Petrasek (2014) Liquidity risk in stock returns: An event-study perspective, Journal of Banking \& Finance 45, 72-83.

M. M. Carhart (1997) On persistence in mutual fund performance, Journal of Finance 52 (1), $57-82$.

D. Chai, R. Faff \& P. Gharghori (2010) New evidence on the relation between stock liquidity and measures of trading activity, International Review of Financial Analysis 19 (3), 181-192.

D. Chai, R. Faff \& P. Gharghori (2013) Liquidity in asset pricing: New Australian evidence using low-frequency data, Australian Journal of Management 38 (2), 375-400. 
H. Chan \& R. Faff (2005) Asset pricing and illiquidity premium, Financial Review 40, $429-458$.

Y. Y. Chang, R. Faff \& C. Hwang (2010) Liquidity and stock returns in Japan: New evidence, Pacific-Basin Finance Journal 18, 90-115.

T. Chiang \& D. Zheng (2011) Liquidity as a Price Factor: Evidence from International Markets Midwest Finance Association, 2012 Annual Meetings Paper, Available at SSRN: http://ssrn.com/abstract=1928261.

T. Chordia, R. Roll \& A. Subrahmanyam (2000) Commonality in liquidity, Journal of Financial Economics 56 (1), 3-28.

T. Chordia, A. Subrahmanyam \& V. R. Anshuman (2001) Trading activity and expected stock returns, Journal of Financial Economics 59, 3-32.

T. Chordia, S. W. Huh \& A. Subrahmanyam (2009) Theory-based illiquidity and asset pricing, Review of Financial Studies 22 (9), 3629-3668.

V. T. Datar, N. Y. Naik \& R. Radcliffe (1998) Liquidity and stock returns: An alternative test, Journal of Financial Markets 1, 203-219.

M. Donadelli \& L. Prosperi (2012) On the role of liquidity in emerging markets stock prices, Research in Economics 66 (4), 320-348.

J. Drienko, T. Smith \& A. Von Reibnitz (2018) A review of the return-illiquidity relationship, Critical Finance Review 7, 1-45.

V. R. Eleswarapu \& M. Reinganum (1993) The seasonal behavior of liquidity premium in asset pricing, Journal of Financial Economics 34, 373-386.

R. F. Engle \& S. Manganelli (2004) CAViaR: Conditional autoregressive value at risk by regression quantiles, Journal of Business $\&$ Economic Statistics 22 (4), 367-381.

E. F. Fama \& K. R. French (1993) Common risk factors in the returns on stocks and bonds, Journal of Financial Economics 33, 3-56.

K. Y. L. Fong, C. W. Holden \& C. Trzcinka (2014) What are the best liquidity proxies for global research? Available at SSRN: http://ssrn.com/abstract=1558447 or http://dx. doi.org/10.2139/ssrn.1558447.

J. Foran, M. C. Hutchinson \& N. O' Sullivan (2014) The asset pricing effects of UK market liquidity shocks: Evidence from tick data, International Review of Financial Analysis 32, 85-94.

P. Gharghori, H. Chan \& R. Faff (2007) Are the Fama-French factors proxying default risk? Australian Journal of Management 32, 223-250.

E. C. Galariotis \& E. Giouvris (2007) Liquidity commonality in the london stock exchange, Journal of Business Finance $\mathcal{E}$ Accounting 34 (1-2), 374-388.

M. Gibbons, S. Ross \& J. Shanken (1989) A test of the efficiency of a given portfolio, Econometrica 57, 1121-1152.

R. Y. Goyenko \& A. D. Ukhov (2009) Stock and bond market liquidity: A long-run empirical analysis, Journal of Financial and Quantitative Analysis 44 (1), 189-212.

R. Y. Goyenko, C. W. Holden \& C. A. Trzcinka (2009) Do liquidity measures measure liquidity? Journal of Financial Economics 92 (2), 153-181.

A. B. S. Gulati (2011) Quantile regression analysis of exchange rate exposure in cross-country sector portfolios, Midwest Finance Association 2012 Annual Meetings Paper.

J. Hasbrouck (2009) Trading costs and returns for US equities: Estimating effective costs from daily data, The Journal of Finance 64 (3), 1445-1477.

K. Hou, C. Xue \& L. Zhang (2017) Replicating Anomalies (No. w23394), National Bureau of Economic Research.

R. D. Huang \& H. R. Stoll (2001) Tick size, bid-ask spreads, and market structure, Journal of Financial and Quantitative Analysis 36, 503-522. 
G. Huberman \& D. Halka (2001) Systematic liquidity, Journal of Financial Research 24 (2), 161-178.

G. Jacoby, D. J. Fowler \& A. A. Gottesman (2000) The capital asset pricing model and the liquidity effect: A theoretical approach, Journal of Financial Markets 3, 69-81.

C. Jones (2002) A century of stock market liquidity and trading costs, Working Paper. Columbia University.

R. Koenker \& G. Bassett (1978) Regression quantiles, Econometrica 46 (1), 33-50.

M. Keene \& D. Peterson (2007) The important of liquidity as a factor in asset pricing, Journal of Financial Research 30, 91-109.

A. Kyle (1985) Continuous auctions and insider trading, Econometrica 53 (6), 1315-1335.

K. S. Lam \& L. H. Tam (2011) Liquidity and asset pricing: Evidence from the Hong Kong stock market, Journal of Banking \& Finance 35 (9), 2217-2230.

K. H. Lee (2011) The world price of liquidity risk, Journal of Financial Economics 99, 136-161.

D. A. Lesmond, J. P. Ogden \& C. A. Trzcinka (1999) A new estimate of transaction costs, Review of Financial Studies 12 (5), 1113-1141.

H. Li, R. Novy-Marx \& M. Velikov (2017). Liquidity risk and asset pricing, Manuscript submitted for publication.

S. X. Liang \& J. K. C. Wei (2012) Liquidity risk and stock returns around the world, Journal of Banking and Finance 36, 3274-3288.

M. Limkriangkrai, R. Durand \& I. Watson (2008) Is liquidity the missing link? Accounting and Finance 48, 829-845.

W. Liu (2006) A liquidity-augmented capital asset pricing model, Journal of Financial Economics 82, 631-671.

A. Lo \& C. MacKinlay (1990) Data snooping biases in tests of financial asset pricing models, Review of Financial Studies 3, 431-467.

F. A. Longstaff (2010) The subprime credit crisis and contagion in financial markets, Journal of Financial Economics 97, 436-450.

C. Lu \& S. Hwang (2007) Cross-Sectional Stock Returns in the UK Market: The Role of Liquidity Risk. Forecasting Expected Returns. Butterworth-Heinemann.

B. Marshall \& M. Young (2003) Liquidity and stock returns in pure order-driven markets: Evidence from the Australian stock market, International Review of Financial Analysis 12, 173-188.

M. A. Martinez, B. Nieto, G. Rubio \& M. Tapia (2005) Asset pricing and systematic liquidity risk: An empirical investigation of the Spanish stock market, International Review of Economics \& Finance 14 (1), 81-103.

D. Morillo (2000) Income mobility with nonparametric quantiles: A comparison of the US and Germany, Preprint.

P. K. Narayan \& X. Zheng (2010) Market liquidity risk factor and financial market anomalies: Evidence from the Chinese stock market, Pacific-Basin Finance Journal 18 (5), 509-520.

D. Nguyen, S. Mishra, A. Prakash \& D. Ghosh (2007) Liquidity and asset pricing under the three-moment CAPM paradigm, Journal of Financial Research 30, 379-398.

N. H. Nguyen \& K. H. Lo (2013) Asset returns and liquidity effects: Evidence from a developed but small market, Pacific-Basin Finance Journal 21 (1), 1175-1190.

V. G. Papavassiliou (2013) A new method for estimating liquidity risk: Insights from a liquidity-adjusted CAPM framework, Journal of International Financial Markets, Institutions and Money 24, 184-197.

L. Pastor \& R. F. Stambaugh (2003) Liquidity risk and expected stock returns, Journal of Political Economy 111, 642-685. 
R. Roll (1984) A simple implicit measure of the effective bid-ask spread in an efficient market, Journal of Finance 39 (4), 1127-1139.

R. Sadka (2006) Momentum and post-earnings-announcement drift anomalies: The role of liquidity risk, Journal of Financial Economics 80 (2), 309-349.

S.-K. Hur \& C. Y. Chung (2018) A novel measure of liquidity premium: Application to the Korean stock market, Applied Economics Letters 25 (3), 211-215.

S.-K. Hur \& C. Y. Chung \& C. Liu (2018) Is liquidity risk priced? Theory and evidence, Sustainability 10 (6), 1-13.

I. Tsai (2012) The relationship between stock price index and exchange rate in Asian markets: A quantile regression approach, Journal of International Financial Markets, Institutions and Money 22 (3), 609-621.

J. Wang \& L. Chen (2012) Liquidity-adjusted conditional capital asset pricing model, Economic Modelling 29 (2), 361-368.

A. Watanabe \& M. Watanabe (2008) Time-varying liquidity risk and the cross section of stock returns, Review of Financial Studies 21 (6), 2449-2486. 